\title{
Timing of early to mid-cretaceous tectonic phases along North Africa: New insights from the Jeffara escarpment (Libya-Tunisia)
}

\author{
S. Bodin ${ }^{\mathrm{a}, *}$, L. Petitpierre ${ }^{\mathrm{a}}$, J. Wood $^{\mathrm{a}}$, I. Elkanouni $^{\mathrm{b}}$, J. Redfern ${ }^{\mathrm{a}}$ \\ ${ }^{a}$ North Africa Research Group, Basin Studies and Petroleum Geosciences, School of Earth, Atmospheric and Environmental Sciences, The University of Manchester, \\ Williamson Building, Oxford Road, Manchester M13 9PL, United Kingdom \\ ${ }^{\mathrm{b}}$ Libyan Petroleum Institute, Km 7, Gergarish Road, P.O. Box 6431, Tripoli, Libya
}

\section{A R T I C L E I N F O}

\section{Article history:}

Received 28 October 2009

Received in revised form 7 April 2010

Accepted 23 April 2010

Available online 15 May 2010

\section{Keywords:}

Aptian

Albian

Jebel Nefusa

Dahar plateau

Austrian unconformity

\begin{abstract}
A B S T R A C T
The Jeffara escarpment spans $400 \mathrm{~km}$ from southeastern Tunisia to sorthwestern Libya, and marks the northern edge of the Berkine-Ghadames Basin. Its horseshoe shape provides a good 3D control of regional-scale depositional architecture. Historically, the political border between Tunisia and Libya hindered the integration of studies over its entirety, which led to the establishment of separate litho-biostratigraphic frameworks. Field-work undertaken on both sides of the border has allowed the unification of lithostratigraphic schemes developed in both countries. Published stratigraphic ages of the different formations and members are compared and integrated in order to propose a unified bio-lithostratigraphic framework. The correlation of serial sections along the Jeffara escarpment shows that two major tectonic unconformities divide the Early Cretaceous sedimentary pattern. The first one is dated as Late Aptian and is commonly associated with the European "Austrian" tectonic phase. The second, which has previously not been recognized as a regional significant surface in Libya, occurs during the Middle Albian and marks moreover the transition from a siliciclastic to a carbonate-dominated sedimentation regime. These two important regional unconformities form the lower and upper boundaries of the Kiklah-Aïn el Guettar Formations, and can be associated with intra-plate deformation linked with the opening of the central segment of the South Atlantic and the Equatorial Atlantic oceans.
\end{abstract}

(c) 2010 Elsevier Ltd. All rights reserved.

\section{Introduction}

The Jeffara escarpment is an important topographic feature of central North Africa, running from Southeast Tunisia, near Médenine, to North-west Libya, east of Tripoli, for ca. $400 \mathrm{~km}$ (Fig. 1). It marks the northern limit of the Berkine-Ghadames Basin. In Tunisia, the escarpment is also known as the Dahar plateau, and is orientated in a north-south trend. The Jeffara escarpment changes its orientation in Libya, where it is called Jebel Nefusa, and strikes in a WSW-ENE orientation. It is made of Mesozoic sedimentary succession, from which the Early to Mid-Cretaceous represents the upper and best-exposed part.

Despite its lateral continuity, and the fact that it belongs to the same geological system, the political border between Libya and Tunisia has hindered the development of modern regional studies on the Jeffara escarpment, and only a few of them in the early 1960s have been undertaken in both countries. This has lead to a separate evolution of the stratigraphic and sedimentological

\footnotetext{
* Corresponding author. Present address: Institute for Geology, Mineralogy and Geophysics, Ruhr-University Bochum, Universitätsstrasse 150, D-44801 Bochum, Germany.

E-mail address: stephane.bodin@rub.de (S. Bodin).
}

understanding on both sides of the Jeffara escarpment. However, in order to better understand the geodynamic history of Africa, an accurate timing for the different events is necessary in order to compare them on a regional scale. This is not only important for academic purposes, but also for industry, such as petroleum exploration and production for instance, where the basin geodynamic history is of critical importance for the assessment of oil maturation (e.g. Underdown et al., 2007). The separate evolution of the Jeffara escarpment geological understanding has thus likely hampered a better understanding of the regional North Africa geology.

In this study, we present the results of field-work undertaken on both sides of the Tunisian-Libyan border along the Jeffara escarpment. Sedimentological characteristics of Early to MidCretaceous rocks are described and used to unify the conflicting lithostratigraphic units between the two countries. A review of published paleontological findings within these units is presented and used to better constrain their dating. Two regional transects, $\mathrm{N}-\mathrm{S}$ and $\mathrm{E}-\mathrm{W}$, compiling the logged sections and correlating the lithostratigraphic units, are presented. Reconstruction of the temporal and spatial evolution illustrates a number of key tectonic unconformities and allows a better constraint on the geodynamic history of the northern Ghadames Basin. Finally, these results are 

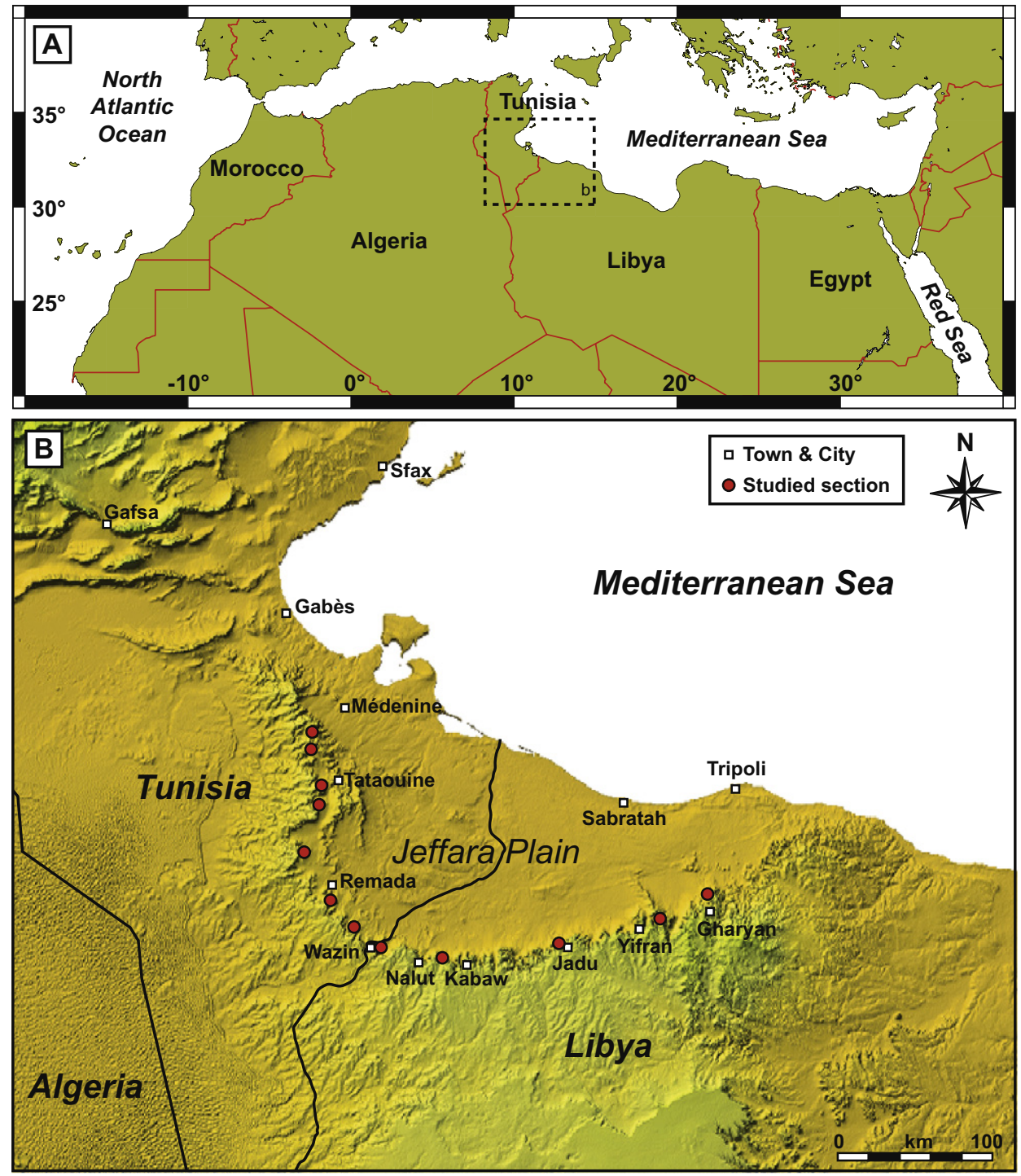

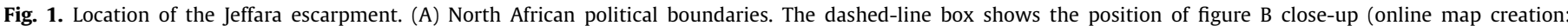

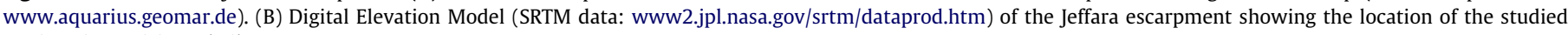
sections in Tunisia and Libya.

placed within the broader context of the African plate tectonic evolution and related to the history of the opening Atlantic Ocean.

\section{Geological setting}

The Jeffara escarpment represents the western and southern limit of the Jeffara coastal plain (Fig. 1) and the northern limit of the Ghadames Basin. This gently southwestward dipping $\left(1-2^{\circ}\right)$ monocline marks the northern end of the Saharan Platform in Tunisia and Libya (Bouaziz et al., 2002). Late Permian to Mesozoic sedimentary rocks are exposed along a ca. $400 \mathrm{~km}$ continuous escarpment. The Late Permian that crops out in the Jebel Tebaga of Medenine (Tunisia; Fig. 2a) is the only known outcropping marine Permian in North Africa (e.g. Newell et al., 1976). In this locality, Late Albian sediments unconformably overlay the Permian (Bouaziz et al., 2002). This feature results from the progressive northward truncation of Mesozoic sediments in Tunisia along the Jeffara escarpment (e.g. Bouaziz et al., 1989). In Libya, a similar progressive truncation of Mesozoic sediment toward the east is as well observed (Fig. 2). However, this truncation does not reach
Permian sediments, but extends down to Middle Triassic (Ladinian) sediments, belonging to the Kurrush Fm (El Hinnawy and Cheshitev, 1975). The stratigraphically most complete Mesozoic sedimentary sequence is thus recorded in the vicinity of the Tunisian-Libyan border. The Jeffara plain is bounded to the north by the Jeffara and Sabratah-Cyrenaica normal faults (Hallett, 2002; Fig. 2b), that separate the subsiding offshore Tripolitana Basin. During the Early Cretaceous, the Ghadames Basin was situated along the northeastern margin of Africa, at an approximate palaeolatitude of $10^{\circ}$ North (Fig. 3).

The geodynamic history of the Ghadames Basin was mostly influenced by the Hercynian and Alpine unconformities (e.g. Boote et al., 1998; Dardour et al., 2004; Underdown et al., 2007; Galeazzi et al., 2010). The Hercynian phase, which culminated in the Late Carboniferous, inverted the northern Ghadames Basin and formed a prominent east-west anticline (called Jeffara-Nefusa Arch; e.g. Boote et al., 1998) that was eroded during the Permian (Hallett, 2002) (Fig. 2b). Sedimentation resumed during the Mesozoic until Palaeocene times. The Alpine phase reactivated and uplifted the Jeffara escarpment during time of dextral strike-slip movement on the basement-rooted Sabratah-Cyrenaica fault system (Anketell 


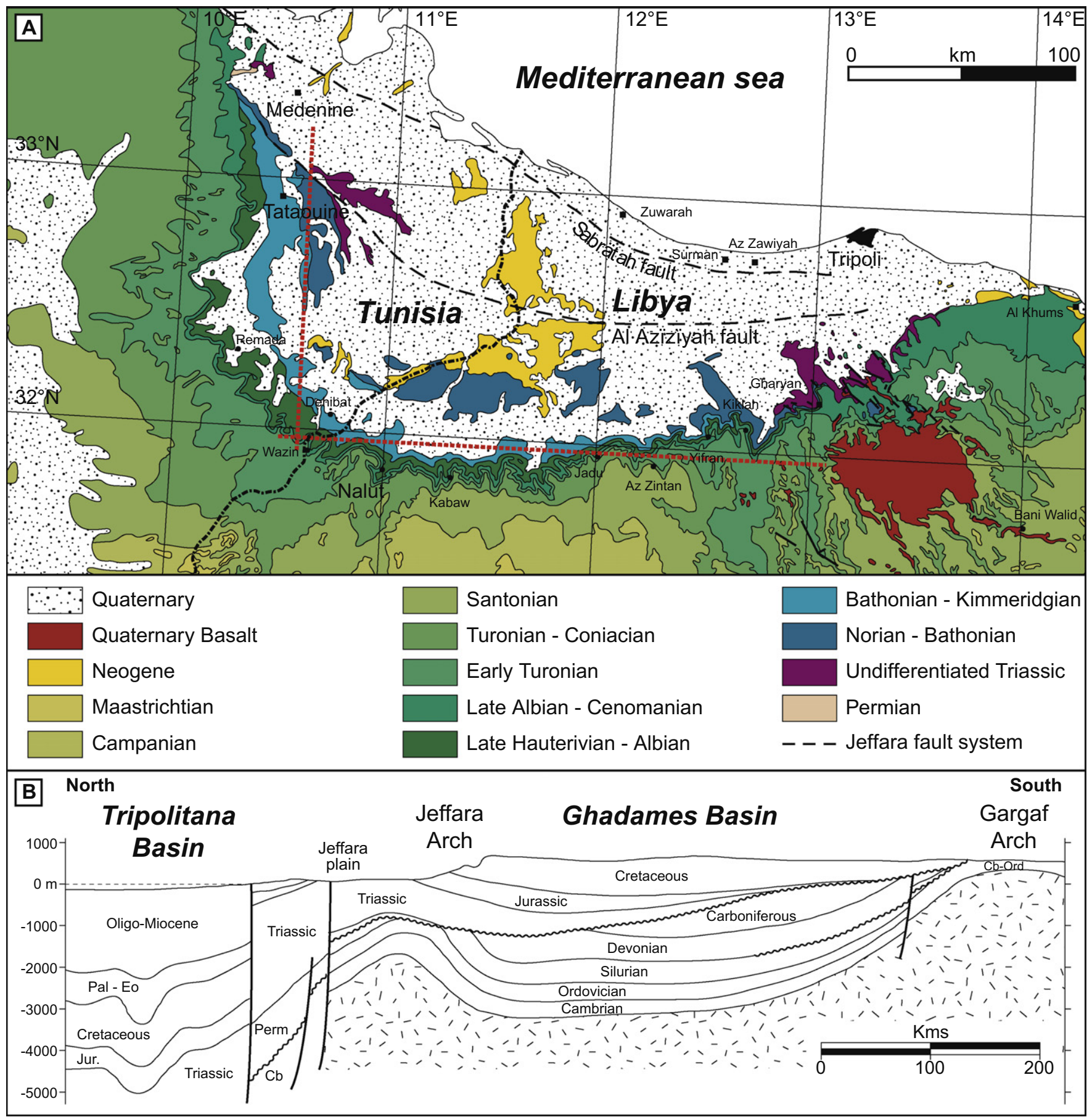

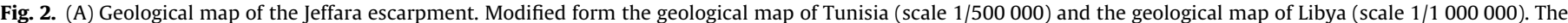

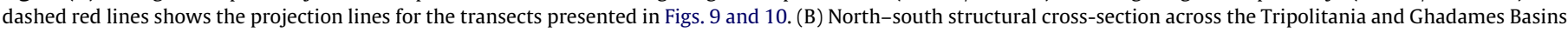
in Libya (modified from Boote et al. (1998)).

and Ghellali, 1991). An Early Cretaceous tectonic phase is moreover reported by various authors and correlated to the "Austrian phase" in Europe (e.g. Echikh, 1998; Bouaziz et al., 2002; Dardour et al., 2004; Underdown et al., 2007), explaining the northward and eastward truncation of the Mesozoic (Triassic to Early Cretaceous) sequence.

Guiraud and Maurin (1992) separated North Africa into two blocks: The West African and the Arabian-Nubian blocks. These are separated by the Benue Trough, the Tenere Basin, the Amguid-Gassi Touil-Algeria and the $10^{\circ} \mathrm{E}$ lineaments (Moulin et al.,
2010). The $10^{\circ} \mathrm{E}$ lineament marks the western boundary of the Saharan Metacraton in the Hoggar-Aïr massif (Abdelsalam et al., 2002; Liégeois et al., 2005) and is known in Libya as the Tihemboka Arch (e.g. Hallett, 2002). The boundary between the two blocks corresponds to weakness zone (series of major fracture and rift zones), such as the Raghane Shear Zone, that separates the Touareg shield from the Sahara Metacraton (Abdelsalam et al., 2002). In Central Tunisia, it is known as the "Axe Nord-Sud" (e.g. Soussi, 2003). The studied area is situated to the east of this lineament. 


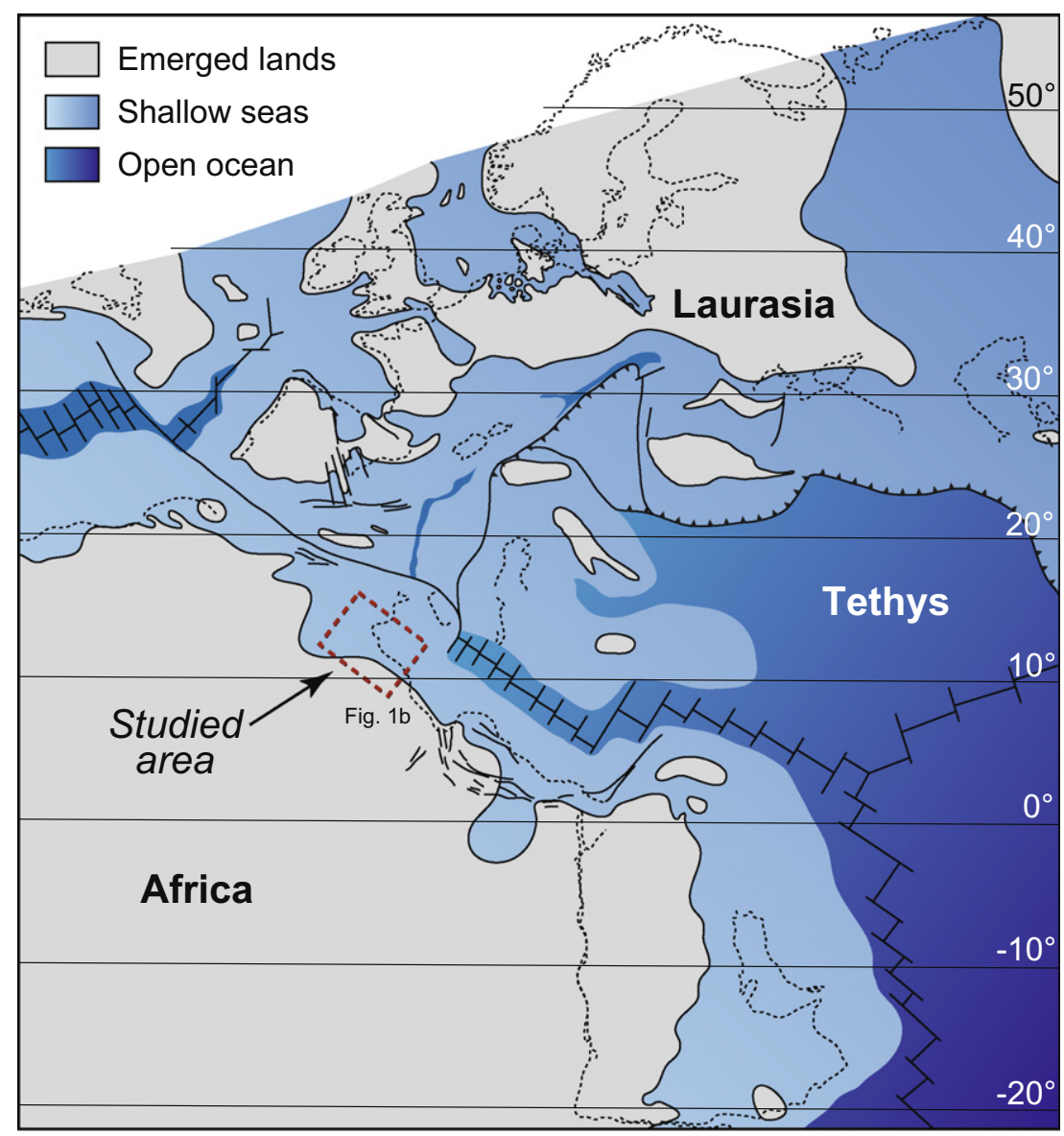

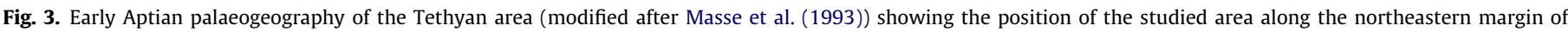
Gondwana. The dashed-line rectangle shows the position of the Fig. 1B.

\section{Methods}

This study is the result of three field-seasons undertaken in South Tunisia and North-West Libya. Sections were measured using a Jacob staff and logged bed-by-bed using traditional fieldsedimentology logging techniques. The GPS coordinates of the measured section are given in Table 1 .

The first two field-seasons (one and half months in total) were undertaken in Tunisia. The field-excursion guide of Ouaja et al. (2002) was used to familiarize the authors to the geology of the Dahar plateau. Key sections, where Early Cretaceous Formations and Members have been defined in South Tunisia, were visited first. A majority of sections presented by Ouaja et al. (2002) have been re-logged in detail and complemented by addition of the uppermost part (Zebbag Fm), which was not logged in detail by previous studies. New sections were also logged in order to complement the Tunisian transect.

The third field-season was undertaken in Libya, in collaboration with the Libyan Petroleum Institute (LPI), starting close to the Tunisian-Libyan border. Libyan sections were first logged and interpreted using the same classification (lithostratigraphic formations and members) applied in Tunisia. This was then compared to the existing Libyan lithostratigraphic scheme to allow unification with the Tunisian nomenclature (see Chapter 4). Key horizons that cross the political border (some of which can be followed over the whole Jeffara escarpment) were used to subdivide the sedimentary succession. The key horizons are: the "Kimmeridgian Bar" and its Libyan equivalent (this horizon is however not present in the vicinity of the Libyan-Tunisian border); the bones-bed between the
Table 1

GPS coordinates (base and top) of the measured sections.

\begin{tabular}{|c|c|c|c|c|}
\hline \multirow[t]{2}{*}{ Section name } & \multicolumn{2}{|l|}{ Base } & \multicolumn{2}{|l|}{ Top } \\
\hline & Latitude & Longitude & Latitude & Longitude \\
\hline Bir Miteur & N33.14905 & E10.28725 & N33.14465 & E10.28237 \\
\hline BirThelathine & N32.73852 & E10.30251 & N32.73555 & E10.29394 \\
\hline Chenini & N32.91682 & E10.27263 & N32.90957 & E10.27194 \\
\hline Dehibat I & N32.07724 & E10.56537 & N32.07013 & E10.55396 \\
\hline Dehibat II & N32.07814 & E10.52184 & N32.07474 & E10.52054 \\
\hline Douiret Ancien & N32.86795 & E10.29146 & N32.87209 & E10.29146 \\
\hline Gharyan & N32.26850 & E13.02995 & N32.26524 & E13.03389 \\
\hline Ghomrassen I & N33.08921 & E10.28937 & N33.10380 & E10.27310 \\
\hline Ghomrassen II & N33.11741 & E10.25600 & N33.12342 & E10.24980 \\
\hline Jadu & N31.96136 & E12.00783 & N31.94865 & E12.00792 \\
\hline Jebel Charenn & N32.84098 & E10.30526 & N32.84034 & E10.29973 \\
\hline Jebel Oum ed Diab & N32.49934 & E10.21321 & N32.49536 & E10.21069 \\
\hline Ksar Jraa & N33.16180 & E10.24565 & N33.15521 & E10.23907 \\
\hline Kiklah I & N32.13739 & E12.64838 & N32.13185 & E12.65097 \\
\hline Kiklah II & N32.05594 & E12.71318 & N32.05598 & E12.70987 \\
\hline Jebel Ltime & N32.79256 & E10.35363 & N32.78506 & E10.33743 \\
\hline Merbah el Asfer & N32.91596 & E10.35714 & N32.90939 & E10.34618 \\
\hline El Mjabrah & N31.87661 & E11.1 & N31.86796 & E11.17876 \\
\hline Oued el Khil I & N33.20052 & E10.26709 & N33.20242 & E10.26804 \\
\hline Oued el Khil II & N33.16443 & E10.25939 & N33.16301 & E10.25919 \\
\hline Remada I & N32.23333 & E10.40750 & N32.22603 & E10.39621 \\
\hline Remada II & N32.25640 & E10.45037 & N32.25 & E10.44095 \\
\hline Shakshuk & N31.98896 & E11.98422 & N31.98289 & E11.97786 \\
\hline Wazin & N31.97762 & E10.73112 & N31.97014 & E10.72566 \\
\hline
\end{tabular}

Boulouha and Douiret Fm; the highly cemented siliciclastic beds that mark the base of the Aïn el Guettar - Kiklah Fms (easily recognized by the fact that it overlies a soft marly sequence); an 
evaporite horizon within the Kerker - Yifran Mbs; and the uppermost Gattar Mb - Nalut Fm that caps the Jeffara escarpment over its entire length. All age attributions presented in this manuscript derive from literature review integrated with the unified lithostratigraphic nomenclature.

\section{A unified litho- and biostratigraphic framework}

\subsection{Sedimentological description}

The Early to Middle Cretaceous sedimentary succession that is exposed in the Jeffara escarpment can be subdivided into two parts according to the main lithology (Figs. 4 and 5). Siliciclastic deposits dominate the lower part of the sedimentary sequence whereas carbonates dominate the upper part. This subdivision reflects the regional sedimentary trend in North Africa and the transition from the "Continental Intercalaire" to the Upper Cretaceous marine series (e.g. Klitzsch and Squyres, 1990; Lefranc and Guiraud, 1990). Along the Jeffara escarpment, the Early Cretaceous siliciclastic deposits were originally interpreted as being mostly deposited in continental subaerial settings (e.g. El-Zouki, 1980a; Bouaziz et al., 1989; Lefranc and Guiraud, 1990). More recent publications (Hammuda et al., 2000; Ouaja et al., 2002; Cuny et al., 2004; Anderson et al., 2007) have however questioned this interpretation and postulated the dominance of shallow marine tidally-influenced deposits.

\subsubsection{Tunisia}

4.1.1.1. Bir Miteur, Boulouha and Douiret Fms. The Early Cretaceous deposits in Tunisia begin with the Boulouha Fm. This formation overlies the Bir Miteur Fm, dated as Oxfordian-Kimmeridgian (e.g. Ouaja et al., 2002). In the uppermost part of the Bir Miteur Fm, a thick brown dolomitic bed, rich in corals and stromatolites, is present and known by local geologists as the "Kimmeridgian bar" (Fig. 6a; Peybernès et al., 1985). It is dated as Early Kimmeridgian by the presence of the benthic foraminifera Alveosepta jaccardi and the algae Salpingoporella annulata and Trinocladus perplexus (Peybernès et al., 1985; Ben Ismaïl et al., 1989; Kamoun et al., 2003). This feature helps to identify the base of the Boulouha Fm, which is marked by a regional subaerial erosive surface and associated reddish clays or conglomeratic deposits (Barale and Ouaja, 2002; Ouaja et al., 2002).

The Boulouha Fm comprises an alternation of fine sandstone, green marls and yellow ${ }^{1}$ dolomite beds (Fig. 7a). A maximum thickness of $72 \mathrm{~m}$ has been measured in the Merbah el Asfer section. Numerous silicified tree logs, some up to $20 \mathrm{~m}$ long, can be found in this formation (Fig. 6c). The Douiret Fm has a maximum thickness of $110 \mathrm{~m}$ near Tataouine. Its base is marked by channelised and cross-stratified fine sandstone, peculiarly enriched in reptilians teeth and bones, fish teeth (shark, Lepidotes), silicified wood and intraclast. The lower part has a sedimentary pattern similar to the Boulouha Fm, whereas green marls with few occurrences of yellow dolomitic mudstone or wackestone dominate the upper part (maximum of $70 \mathrm{~m}$ in the Jebel Charenn section). The occurrence of these dolomitic beds increases toward the south.

4.1.1.2. Aïn el Guettar Fm. This Formation is principally made of reddish cross-stratified fine to coarse sandstone and siltstone (Fig. 6d), with occasional green marl intervals. The maximum measured thickness was $80 \mathrm{~m}$. Two fining-upward cycles can be identified within this formation, which allow it to be divided into two members; the Chenini and Oum ed Diab Mbs. The upper member is

\footnotetext{
1 For interpretation of color in Figs. 2, 6, 7, 9, and 10 the reader is referred to the web version of this article.
}

moreover characterized by the occurrence of distinctive white mica (Ouaja et al., 2002). The Aïn el Guettar Fm is rich in silicified wood and vertebrate fossils (e.g. Benton et al., 2000). In the northern area (e.g. Chenini section), marine trace fossils Skolithos sp. and Diplocraterion sp. occur at the base of Oum ed Diab Mb (Fig. 6e).

4.1.1.3. Zebbag $\mathrm{Fm}$. The Zebbag $\mathrm{Fm}$ has been divided into three members by previous workers; Rhadouane, Kerker and Gattar Mbs (e.g. M'Rabet et al., 1995; Barale and Ouaja, 2002; Ouaja et al., 2002). The Rhadouane Mb consists of an alternation of bioclastic floatstone to rudstone (rich in bivalves and gastropods; Fig. 7c) and biolaminated mudstone (microbialite), that forms a prominent cliff in the landscape (Fig. 6a). Toward the top, marl intercalations occur. The Rhadouane $\mathrm{Mb}$ is only present in the northern part of the Jeffara escarpment in Tunisia. Its maximum measured thickness is $35 \mathrm{~m}$. The contact with the Kerker Mb is not well defined and corresponds to the transition from a limestone-dominated to a marl-dominated sequence. The Kerker Mb is characterized by an alternation of yellow marls, biolaminated mudstone (microbialite), rich in birdseye structures and fenestrae fabrics, as well as few wackestone. Intense bioturbation is sometime observed in the mudstone (Fig. 7e). A distinctive evaporite marker-horizon (made of gypsum and halite; Fig. 7f) is observed in the northern part of the Jeffara escarpment. The top of the Kerker Mb is marked by the occurrence of bivalves, gastropods, echinoids and an ubiquitous, thick (between 3 and $8 \mathrm{~m}$ ), yellow marl horizon. Measured thicknesses vary between 50 and $140 \mathrm{~m}$.

The Gattar Mb forms the prominent uppermost cliff of the Jeffara escarpment. It consists of brown dolomitic limestone, with the occurrence of gastropods, pelecypods and rudists (e.g. Razgallah et al., 1994; M'Rabet et al., 1995; Abdallah and Meister, 1997). Rare chert nodules can also be observed. The dolomitization is the product of early diagenetic processes (Chaabani et al., 2003) and can be very intense in some areas (Fig. $7 \mathrm{~g}$ ), leading to the complete destruction of the primary sedimentary fabric. Reef-like structures have also been observed in the Gattar Mb (Ouaja et al., 2002). The maximum measured thickness is $33 \mathrm{~m}$.

At the base of the Zebbag Fm, in some localities of the northern part of the studied area, channelized coarse clastic deposits have been observed. They reach a maximum thickness of $18 \mathrm{~m}$ in the Oued el Khil section. These clastic deposits consist of quartz grains in the southern part, but pass rapidly into carbonate-clastic deposits in the northern part of the studied area. These sandstones show evidence of tidal influence such as herring-bones cross-stratification (Fig. 7b) and contain marine bioturbations and fauna (bivalves and bryozoans fragments). There is a rapid vertical transition between these sands and the Rhadouane Mb (2-3 m thick), showing a progressive disappearance of clastic grains. We propose to name this new lithostratigraphic unit the "Charenn Mb" and place it at the base of the Zebbag Fm. Its name is a reference to the Jebel Charenn, situated between the towns of Douiret and Tataouine, where these deposits were first observed.

\subsubsection{Libya}

The studied interval in Libya is divided into four formations (Fig. 4): Kabaw, Kiklah, Sidi as Sid and Nalut Fms (Banerjee, 1980).

4.1.2.1. Kabaw Fm. The Kabaw Fm consists of an alternation of fine grained sandstone, green marls and yellow dolomite beds, and is characterized by the occurrence of silicified wood remains (El-Zouki, 1980b). Some logs can reach up to $16 \mathrm{~m}$ long. A bonebed, rich in reptilian and fish teeth and bones, is observed in the lower part of the sedimentary succession. A green marl-dominated sequence, with the occurrence of yellow dolomitic beds, characterizes the uppermost part of the Kabaw Fm (Fig. 6b). Toward the central part of Jebel Nefusa (Shakshuk section), the 
Libya (Jebel Nefusa)

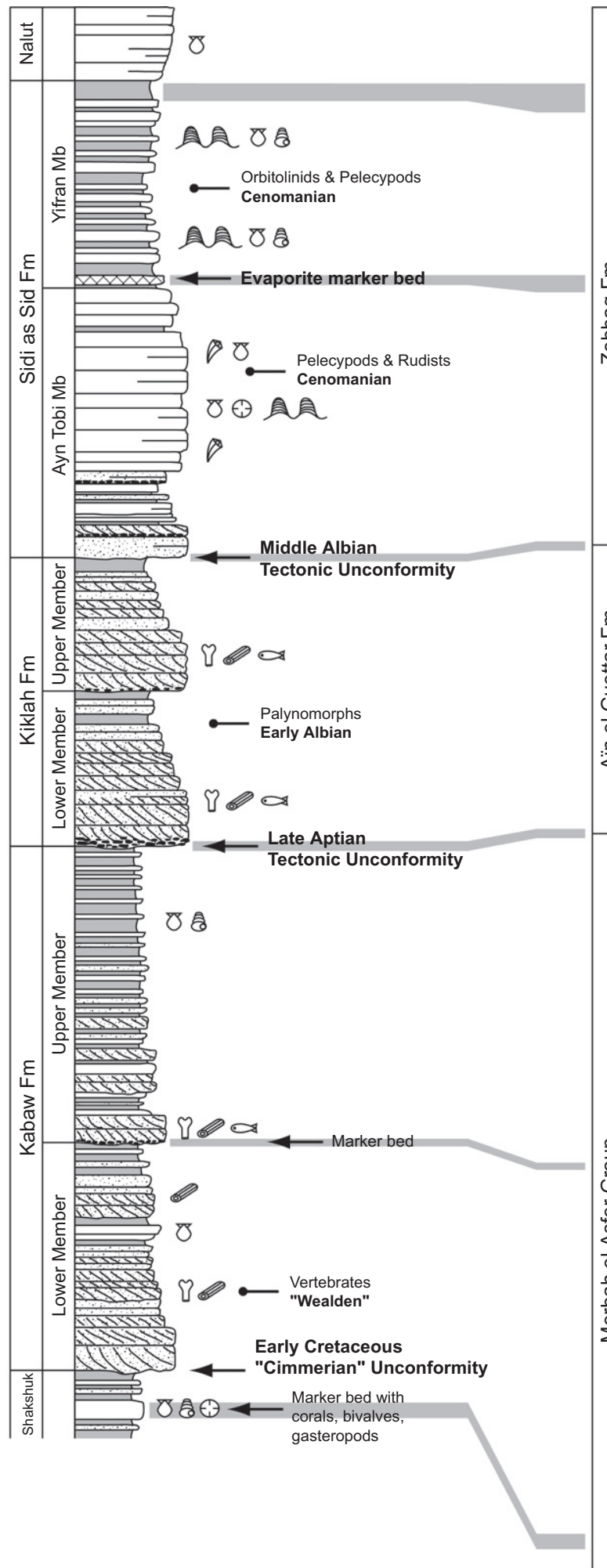

Tunisia (Dahar plateau)

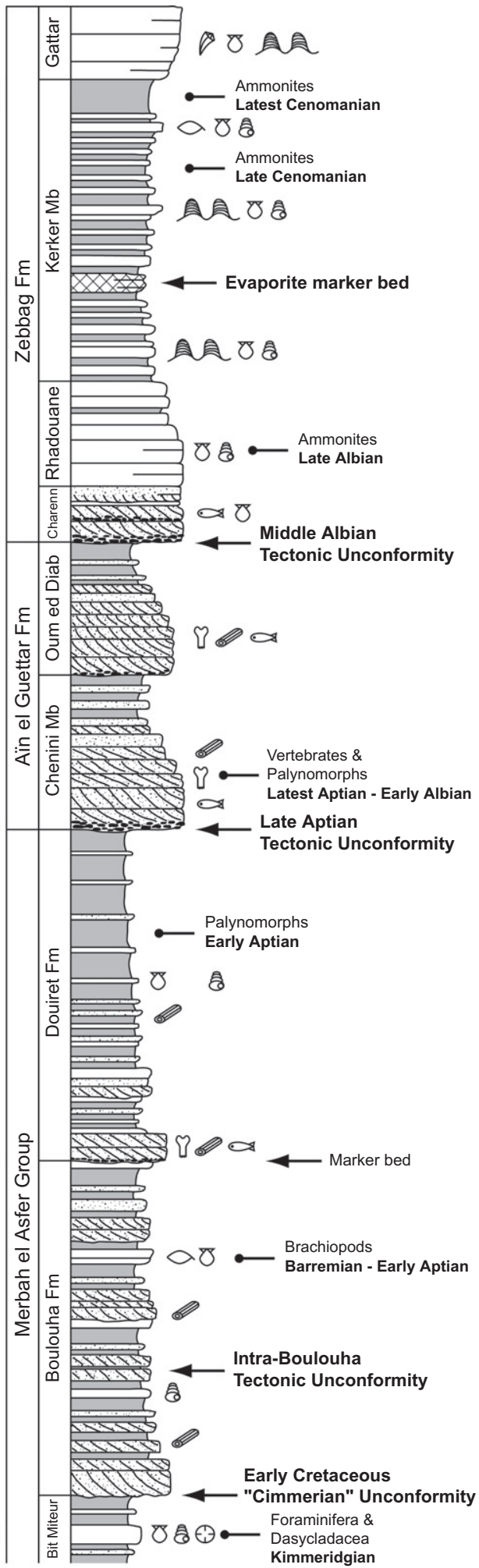

\begin{tabular}{|c|c|c|c|c|c|c|}
\hline 8 & Pelecypods & $\theta$ & Rudists & 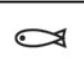 & Fish remains & Sandstone, cross-bedded \\
\hline శి & Gasteropods & 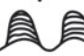 & Microbialites & $\mathscr{G}$ & Silicified wood & Carbonate \\
\hline 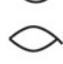 & Brachiopods & $\Theta$ & Corals & ? & Reptilian remains & Evaporite \\
\hline
\end{tabular}

Fig. 4. Synthetic lithostratigraphic column of the Early to Middle Cretaceous succession along the Jeffara escarpment in Libya and Tunisia. No precise thickness is indicated due to important thickness variability along the Jeffara escarpment. 


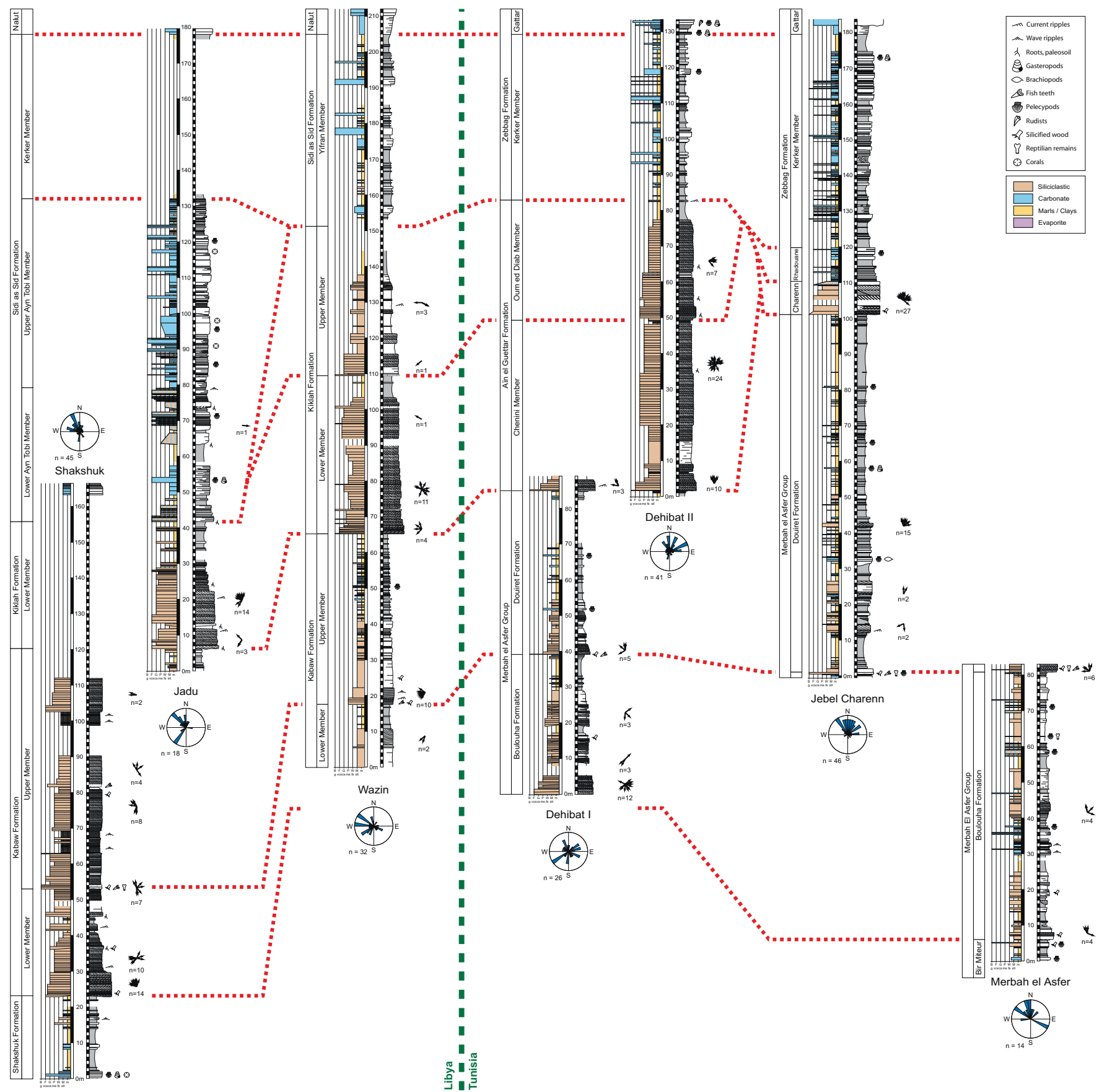

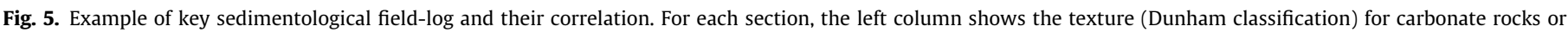

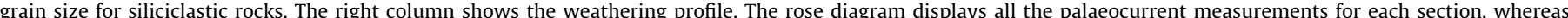

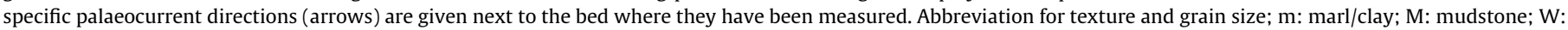
wackestone; P: packstone; G: grainstone; F: floatstone; B: bindstone; slt: silt; fs: fine sand; ms: medium sand; cs: coarse sand; vcs: very coarse sans; g: gravel.

Kabaw Fm becomes sand-dominated and the occurrence of marls or dolomitic bed is rare. In this section, the contact with the underlying Shakshuk Fm is well exposed and characterized by channelized fluvial deposits. Within the upper part of the Shakshuk Fm, a 2 m thick yellow dolomitic bed, rich in bivalves, gastropods and coral remains, is also observed. The Kabaw Fm is absent in the eastern part of the studied area. The maximum observed thickness is $110 \mathrm{~m}$ in the El Mjabrah section. The lowermost part was however not exposed in this section.

4.1.2.2. Kiklah Fm. Along the Jebel Nefusa, significant lateral facies variations characterize the Kiklah Fm (El-Zouki, 1980b). Three main facies regions can be distinguished. In the western part, the Kiklah Fm comprises reddish cross-stratified fine to coarse sandstone and siltstone, with few occurrences of green marls (Fig. 6f). Numerous silicified tree logs, as well as vertebrate bones and teeth, are present. Two fining-upward cycles can be distinguished within the Kiklah Fm in the western region. In the central region (Jadu, Shakshuk and Kiklah sections), as with the Kabaw Fm, the Kiklah $\mathrm{Fm}$ is dominated by sandstone with rare occurrences of red silty clay intervals. In the easternmost logged section (Gharyan), the Kiklah Fm is characterized by the predominance of conglomeratic facies interbedded with clay-rich mudstone. The base consists of carbonate pebbles, reworked from the underlying Abu Ghylan 

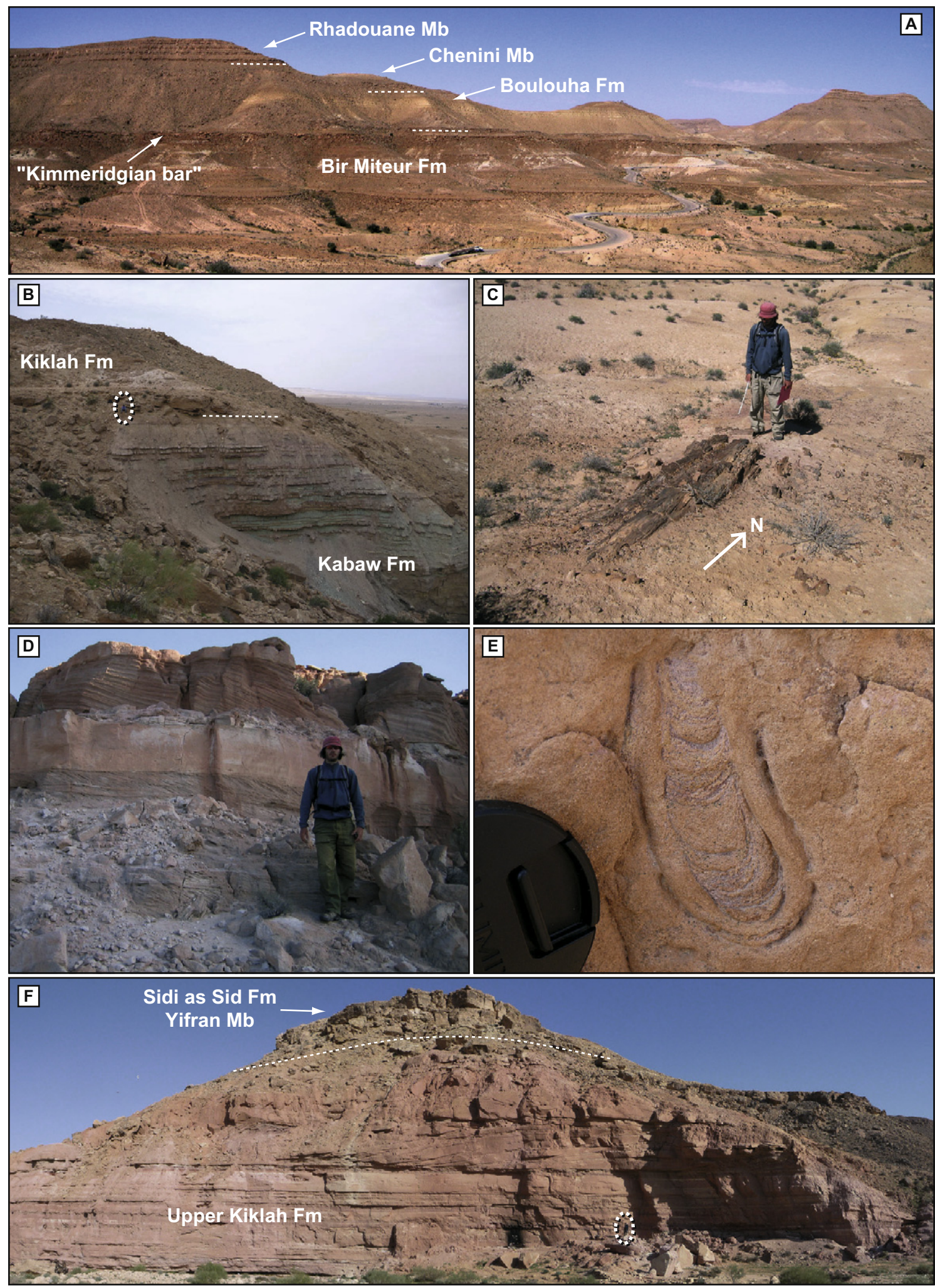

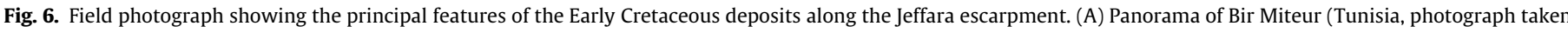

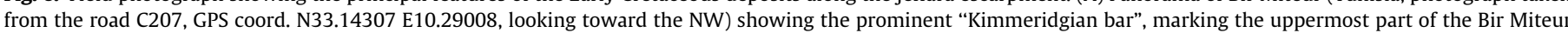

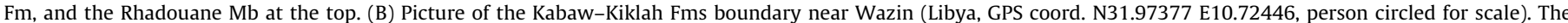

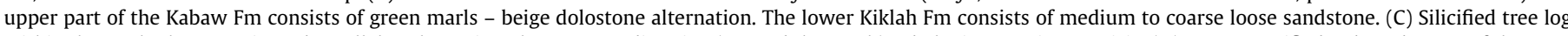

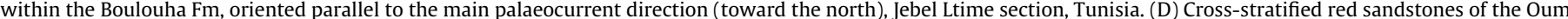

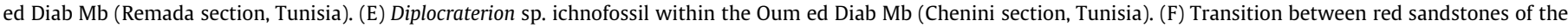

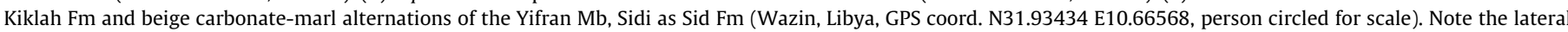
accretion packages near the top of the Kiklah Fm. 

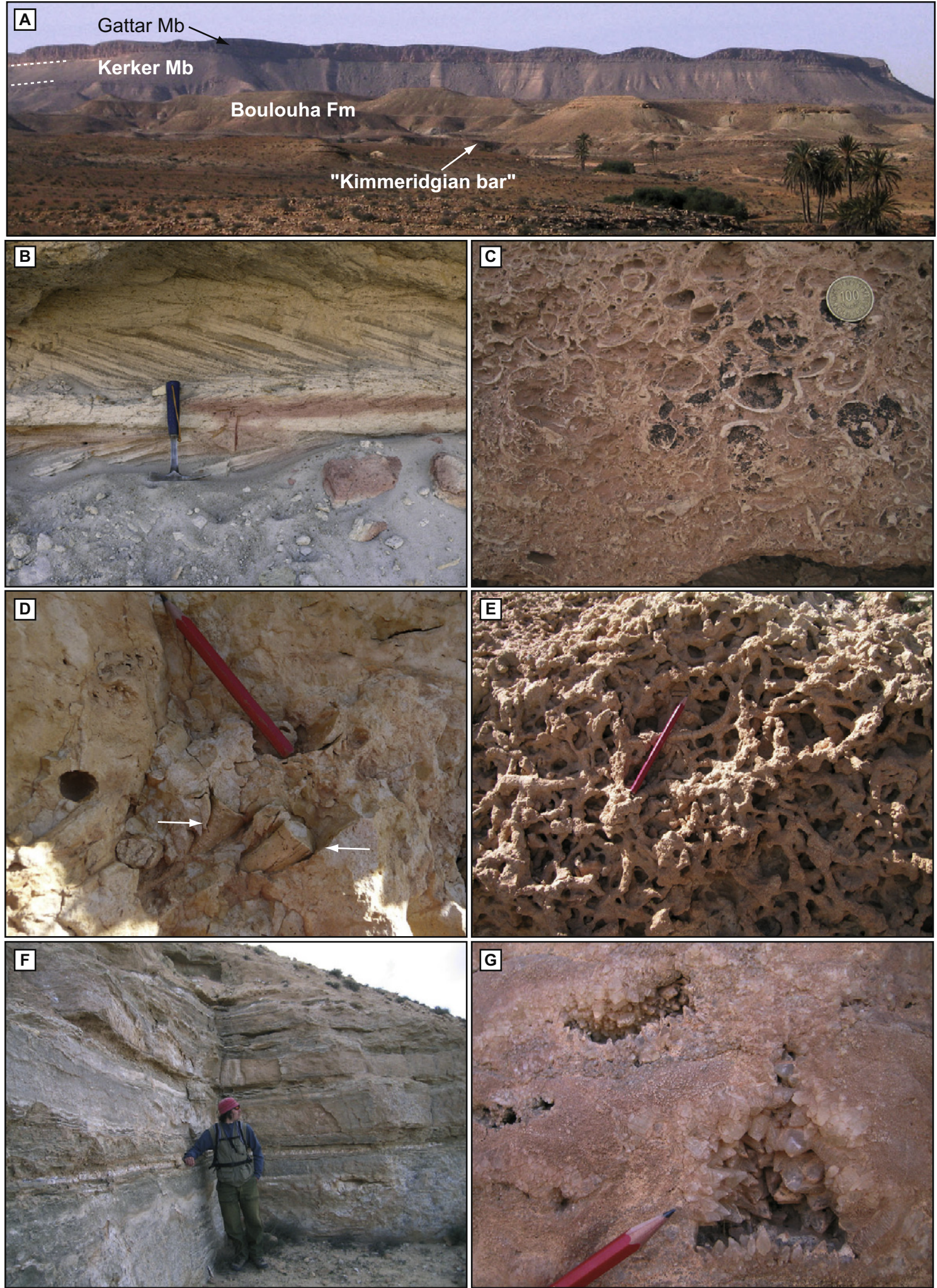

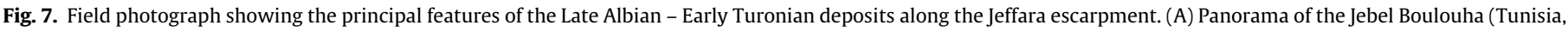

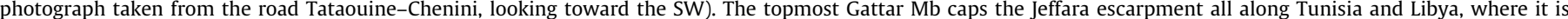

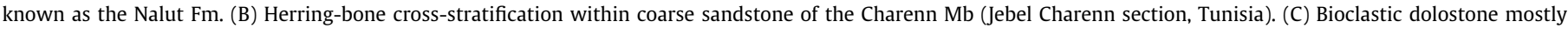

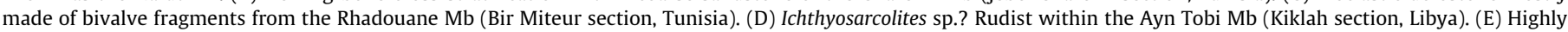

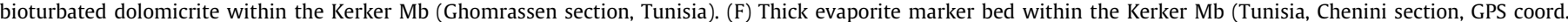
N32.91157 E10.27155). (G) Large vugs interpreted as being rudists molds within the highly dolomitized Gattar Mb (Douiret Ancien section, Tunisia). 
Fm. Two fining-upward sequences are present in this section. The measured thicknesses vary between 37 and $88 \mathrm{~m}$.

4.1.2.3. Sidi as Sid Fm. The following Sidi as Sid Fm is divided into two members: Ayn Tobi and Yifran Mbs (e.g. El-Bakai, 1997; Hallett, 2002). The Ayn Tobi Mb comprises dolomitic bioclastic floatstone to rudstone (rich in pelecypods, rudists and gastropods; Fig. 7d) and biolaminated mudstone (microbialite). There is a gradational transition between the Ayn Tobi and the Yifran Mbs. The latter is characterized by the alternation of yellow marls and biolaminated mudstones (microbialites) with birdseye and fenestrae fabrics. The uppermost part is marked by a thick $(<10 \mathrm{~m})$ yellow marl interval. The presence of a bedded evaporitic horizon near the base of the Yifran $\mathrm{Mb}$ is also observed is some sections. The Ayn Tobi Mb has a measured maximum thickness of $64 \mathrm{~m}$, and the Yifran Mb thickness varies between 45 and $96 \mathrm{~m}$.

In the Jadu section, the first $37 \mathrm{~m}$ of the Ayn Tobi Mb are characterized by the occurrence of siliciclastic deposits (silt to very coarse sandstone, with a carbonate matrix) interbedded with the dolomitic sediments. The Ayn Tobi Mb - Kiklah Fm limit is marked by an erosive surface and reworked palaeosol (calcrete) clasts.

4.1.2.4. Nalut Fm. The Nalut Fm (also known as the Gharyan Fm) caps the Jebel Nefusa over its entire length. This brown limestone unit is made of crystalline dolomite and rare chert horizons and nodules. Rare, poorly preserved pelecypods have been reported (Hallett, 2002).

\subsection{Unified lithostratigraphic scheme between Libya and Tunisia}

The lithostratigraphic correlation between Libyan and Tunisian Formations and Members is straightforward utilising the serial logging technique used here (Fig. 8). The Dehibat and Wazin sections, situated in Tunisia and Libya, respectively, are perfect for this purpose because of their close proximity (there is only ca. $20 \mathrm{~km}$ between them) and their relative completeness regarding the Early to Mid-Cretaceous lithostratigraphic succession.

Thus, the Kabaw Fm of Libya is the equivalent of the combined sedimentary package of the Boulouha and Douiret Fms in Tunisia. They share the same lithological and sedimentological features, i.e. an alternation of green marls, fine to medium sandstones and bioclastic dolomitic beds. The upper part of the Kabaw section consists of the alternation of thick green marls layers with dolomitic mudstone, which can be directly correlated to the thick green marl interval at the top of the Douiret Fm. The basal Douiret Fm sandstone bed, rich in fossilized fish, reptile and wood debris (Ouaja et al., 2002), can also be recognized in western Libya. We propose to subdivide the Kabaw Fm into two members, the Lower and Upper Kabaw Mbs, which are the equivalent of the Boulouha and Douiret Fms, respectively. The correspondence between the Kabaw Fm and the Boulouha-Douiret Fms is further confirmed by the close correspondence of lithostratigraphic unit thicknesses on both sides of the border and their relative position regarding the Late Aptian tectonic unconformity. We moreover propose the correlation between the Tunisian "Kimmeridgian bar" of the Bir Miteur Fm and the coral-rich dolomitic bar of the upper part of the Shakshuk Fm.

The Libyan Kiklah Fm is equivalent to the Aïn el Guettar Fm in Tunisia. The correspondence of these two formations was already mentioned by Tunisian workers (e.g. Bouaziz et al., 1989) and is further confirmed by the similar thickness of the two formations on both sides of the border, their similar age dating and their relative position regarding the Late Aptian and Middle Albian tectonic unconformities (see below). The Tunisian subdivision of this formation into two members, the Chenini and Oum ed Diab Mbs, can also be recognized in Libya, and thus allows the subdivision of the Kiklah Fm into a Lower and Upper Kiklah Mbs. In the Dehibat-Wazin region, the Libyan Yifran and Tunisian Kerker Mbs directly overlie the Kiklah and Aïn el Guettar Fms, respectively. These two members have the same lithological characteristic, i.e. dominated by the alternation of dolomitic mudstone-wackestone and yellow marls, and are thus Tunisian and Libyan equivalent. The top of the Jeffara escarpment is capped by a thick succession of brown massive dolomitic beds, attributed to the Gattar Mb in Tunisia and Nalut Fm in Libya (e.g. Ben Youssef, 1999).

The Tunisian Rhadouane Mb can be correlated to the Ayn Tobi $\mathrm{Mb}$ in Libya based on their common lithological characteristic and position relative to the Kerker-Yifran Mbs. In the Jadu area, the lower part of the Ayn Tobi Mb is made of siliciclastic rocks being rapidly replaced by a carbonate-dominated sedimentation. This is also seen in the Charenn - Rhadouane Mbs succession in Tunisia and further supports the lithostratigraphic correspondence between the Ayn Tobi and the Rhadouane Mbs.

\subsection{Dating of formations and members}

There is a significant variance in the published age dates for the sediment exposed along the Jeffara escarpment between Libya and Tunisia. This can be assessed when comparing published review literature, such as Tawadros (2001) or Hallett (2002) for Libya, and Barale and Ouaja (2002) for Tunisia. This discrepancy arises from the fact that since the late 1960s and the study of Busson (1967), no published field-work has been undertaken by the same research group on both sides of the Tunisian-Libyan border. However, accurate dating of these rocks is important in order to assess the timing and control of the deformations phases in North Africa. Table 2 gives a summary of published stratigraphically significant palaeontologic finds and the subsequent age attribution of lithostratigraphic units in the Jeffara escarpment.

In Tunisia, the Boulouha Fm has yielded the brachiopod Loriolithyris russillensis (Peybernès et al., 1996), which led Barale and Ouaja (2002) to propose a latest Hauterivian? - Early Aptian age for this formation (see also Ben Youssef, 1999). The Douiret Fm has been dated as Early Aptian with the help of palynomorph assemblages (Ben Ismaïl, 1991). Cuny et al. (2004) also identified hybodont sharks (Hybodus sp., Priohybodus arambourgi) and marine ray ("Rhinobatus" sp.) remains from this Formation. The age of the Kabaw Fm in Libya is more controversial due to the absence of stratigraphically precise finds. The assemblage of dinosaur vertebra (Spinosaurus?), shark teeth (Priohybodus arambourgi), fish scales and teeth (Lepidotes sp.), crocodile teeth and turtle shells indicate a Wealden age (i.e. Valanginian-Barremian) according to El-Zouki (1980b). The lithostratific equivalence of the Kabaw Fm with the Boulouha-Douiret Fms, as well as their similar position relative to the "Austrian" unconformity, allows us to propose an equivalent age for these formations, i.e. a latest Hauterivian? Early Aptian age, implying an Early Cretaceous hiatus at the base of the Kabaw-Boulouha Fms (Fig. 8). This is moreover in agreement with Belhaj (1996) who stated: “Despite extensive palynological analyses of many wells, the Neocomian has not been identified in the study area", i.e. the western Sirt Basin, "nor in the subsurface of the Ghadämis Basin".

The Tunisian Aïn el Guettar Fm has been dated as Early Albian by Bouaziz et al. (1988) and Benton et al. (2000) with the help of an important fish and reptilian fauna (fishes Protolamna sp., Cretodus?, Lepidotes, cf. Anoemodus, cf. Caturus, Neoceratodus africanus, dinosaurian Carcharodontosaurus saharicus and Spinosaurus sp. (see also Buffetaut and Ouaja, 2002). Ben Ismaïl (1991) attributed the Chenini Mb to the Late Aptian - Early Albian based on palynological assemblages. Cuny et al. (2004) report the presence of neoselachian sharks (Cretodus semiplicatus, cf. Protolamna, cf. Scapanorhynchus, Onchopristis dunklei) and hybodont Tribodus 


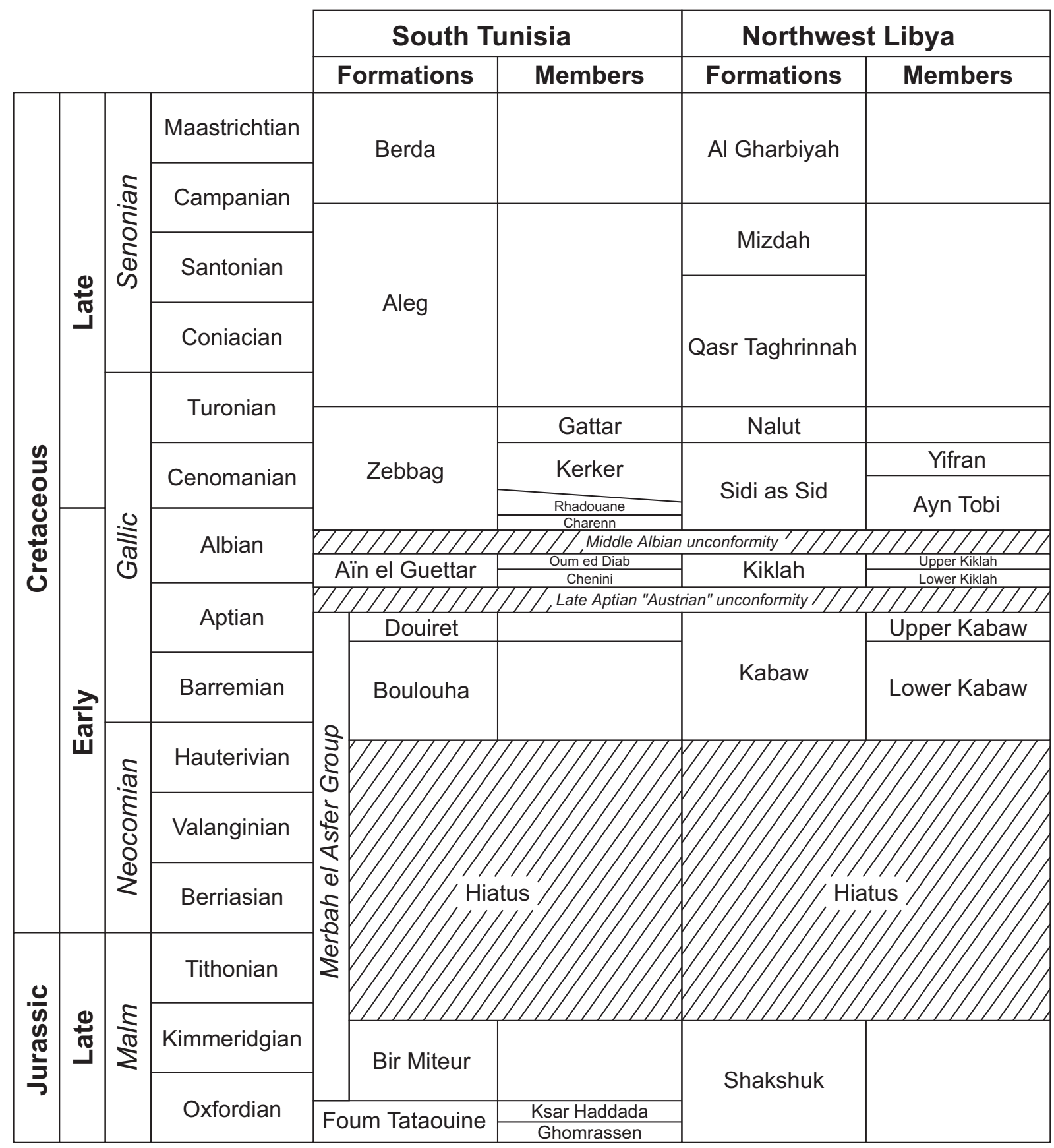

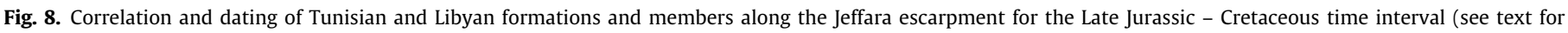
further details).

tunisiensis. In Libya, the dating of the Kiklah Fm remains controversial and is generally thought to be Aptian-Albian in age without further precision (e.g. Tawadros, 2001; Hallett, 2002). Palynological studies however point towards an Early Albian age (Ward et al., 1987; Tekbali, 2000) based on the presence of Classopollis, ephedroids, Callialasporites, Araucariacites, Eucommiidites, Aequitriradites, Triporoletes, Locopodiacidites, Klukisporites, Cicatricosisporites, Perotriletes pannuceus and Afropollis. The lithostratigraphic equivalence of the Kiklah Fm with the Aïn el Guettar Fm would support a latest Aptian? - Early Albian age for these formations.

In the Chott and Medenine areas (southern Central Tunisia), the Rhadouane $\mathrm{Mb}$ is dated as Late Albian (Inflata and Substuderi ammonite zone) with ammonite findings (Knemiceras syriacum, $K$. gracile, K. compressum, K. aegyptiacum, Eopachydiscus aff. marcianus,
Engonoceras aff. saadense, E. toussainti; Ben Youssef et al., 1985; Abdallah and Memmi, 1994). Along the Jeffara escarpment, the Rhadouane $\mathrm{Mb}$ is also thought to be Late Albian, despite the absence of any precise dating in published literature. In Libya, its lithostratigraphic equivalent, the Ayn Tobi Mb, is rich in bivalves. The presence of Exogyra flabellata, E. delettrei, E. columba, Trigonia beyrichi, Avicula cenomaniensis, Corbula striatula, Ichthyosarcolites triangularis and I. bicarinatus (Christie, 1955; Desio et al., 1963) allowed El Hinnawy and Cheshitev (1975) to propose a Cenomanian age for this formation (see also Megerisi and Mamgain, 1980). This lithostratigraphic unit appears thus to be time-transgressive from Late Albian in Tunisia to Cenomanian in Libya. This can also be demonstrated by the location of the evaporite marker-horizon in the Kerker-Yifran Mbs which acts as an effective timeline. Indeed, 
Table 2

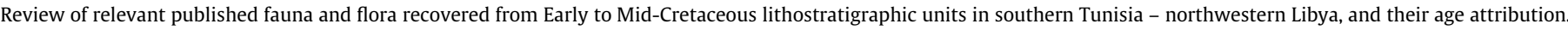

\begin{tabular}{|c|c|c|c|}
\hline Formation & Member & Organisms & Age attribution \\
\hline $\begin{array}{l}\text { Tunisia } \\
\text { Boulouha }\end{array}$ & & Brachiopod Loriolithyris russillensis & $\begin{array}{l}\text { Latest Hauterivian? - Early Aptian (Peybernès } \\
\text { et al., 1996; Barale and Ouaja, 2002) }\end{array}$ \\
\hline Douiret & & Palynomorphs & Early Aptian (Ben Ismaïl, 1991) \\
\hline Aïn el Guettar & & $\begin{array}{l}\text { Palynomorphs, fishes Protolamna sp., Cretodus?, Lepidotes, cf. Anoemodus, cf. Caturus, } \\
\text { Neoceratodus africanus, dinosaurian Carcharodontosaurus saharicus and Spinosaurus } \\
\text { sp. }\end{array}$ & $\begin{array}{l}\text { Late Aptian - Early Albian (Ben Ismaïl, 1991) } \\
\text { Early Albian (Bouaziz et al., 1988; Benton et al., } \\
\text { 2000) }\end{array}$ \\
\hline Zebbag & $\begin{array}{l}\text { Rhadouane } \\
\text { Kerker } \\
\text { Gattar }\end{array}$ & $\begin{array}{l}\text { Ammonites Knemiceras syriacum, K. gracile, K. compressum, K. aegyptiacum, } \\
\text { Eopachydiscus aff. marcianus, Engonoceras aff. saadense, E. toussainti } \\
\text { Ammonite Neolobites medeninensis } \\
\text { Ammonites (below the Gattar Mb) Calycoceras sp., Vascoceratidae sp., Choffaticeras } \\
\text { aff. massipianum, C. aff. securiforme, C. gr. pavill-ieri, C. luciae, N. (Betiokyites) gr. pioti, } \\
\text { Vascoceras sp., V. aff. obessum, Fagesia sp., Thomasites rollandi, Hoplitoides gr. wohlt- } \\
\text { manni, Neoptychites gr. cephalatus }\end{array}$ & $\begin{array}{l}\text { Late Albian (Ben Youssef et al., 1985; Abdallah } \\
\text { and Memmi, 1994) } \\
\text { Cenomanian (Busson, 1967) } \\
\text { Early Turonian (Razgallah et al., 1994; Abdallah } \\
\text { and Meister, 1997) }\end{array}$ \\
\hline \multicolumn{4}{|l|}{ Libya } \\
\hline Kiklah & & $\begin{array}{l}\text { Palynomorphs Classopollis, ephedroids, Callialasporites, Araucariacites, Eucommiidites, } \\
\text { Aequitriradites, Triporoletes, Locopodiacidites, Klukisporites, Cicatricosisporites, } \\
\text { Perotriletes pannuceus, Afropollis }\end{array}$ & Early Albian (Ward et al., 1987; Tekbali, 2000) \\
\hline \multirow[t]{2}{*}{ Sidi as Sid } & Ayn Tobi & $\begin{array}{l}\text { Bivalves Exogyra flabellata, E. delettrei, E. columba, Trigonia beyrichi, Avicula } \\
\text { cenomaniensis, Corbula striatula, Ichthyosarcolites triangula-ris, I. bicarinatus }\end{array}$ & Cenomanian (Christie, 1955; Desio et al., 1963) \\
\hline & Yifran & $\begin{array}{l}\text { Foraminifera Orbitolina concava, Praealveolina cretacea tenuis, Thomasinella punica, } \\
\text { Buccicrenata libyca, Ammomarginulina cf. blanckenhorni, Hemicyclammina cf. sigali, } \\
\text { Gavelinopsis pseudobaccatus }\end{array}$ & Cenomanian (Megerisi and Mamgain, 1980) \\
\hline Nalut & & $\begin{array}{l}\text { Foraminifera Praeglobotrucana cf. stephani, Rotalipora sp., Globotrun-cana sp., } \\
\text { Orbitolina sp., Stensioina sp., Kilianina sp., Thomasinella punica, Cuneolina conica, } \\
\text { Nezzazata gyra }\end{array}$ & Cenomanian (Busson, 1967) \\
\hline
\end{tabular}

this unique event is situated in the middle of the Kerker $\mathrm{Mb}$ in the northern part of the Jeffara escarpment (Fig. 9), but at the base of the Yifran Mb (Fig. 10), underlining the diachronity of the top of the Rhadouane-Ayn Tobi Mbs. This diachronous lithostratigraphic unit nicely exemplifies the Late Albian - Cenomanian sea-level transgression onto the African craton (e.g. Ben Youssef and Peybernès, 1986; Burollet, 1989). However, questions remain about the exact age of the Rhadouane $\mathrm{Mb}$ and the biostratigraphic correlation between the Charenn Mb and the siliciclastic base of the Ayn Tobi Mb.

The Yifran Mb in Libya is dated as Cenomanian with the help of molluscs and foraminifera assemblages (Christie, 1955; Desio et al., 1963). The presence of Orbitolina concava, Praealveolina cretacea tenuis, Thomasinella punica, Buccicrenata libyca, Ammomarginulina cf. blanckenhorni, Hemicyclammina cf. sigali, Gavelinopsis pseudobaccatus confirms this age attribution (Megerisi and Mamgain, 1980). In Tunisia, the equivalent Kerker $\mathrm{Mb}$ is as well dated from the Cenomanian (Busson, 1967) by the presence in its upper part of the ammonite Neolobites medeninensis.

The Gattar $\mathrm{Mb}$ is dated by ammonite biostratigraphy as Early Turonian (Razgallah et al., 1994; Abdallah and Meister, 1997). In Libya, its lateral equivalent (Nalut Fm) was originally dated as Cenomanian (e.g. Christie, 1955; Desio et al., 1963; El Hinnawy and Cheshitev, 1975) using Molluscan fossils. The robustness of this Cenomanian age attribution was however criticised by Busson (1967). Megerisi and Mamgain (1980) attribute to the Nalut Fm a Late Cenomanian-Turonian age based on foraminiferal assemblage (Praeglobotrucana cf. stephani, Rotalipora sp., Globotruncana sp., Orbitolina sp., Stensioina sp., Kilianina sp., Thomasinella punica, Cuneolina conica, Nezzazata gyra). Further north, in Central Tunisia, the Gattar Fm overlays the Bahloul Fm, which marks the Cenomanian-Turonian boundary. This boundary is associated with a second-order maximum flooding surface (e.g. Lüning et al., 2004) and as such, the change from a transgressive sequence (i.e. the Albian-Cenomanian transgression; e.g. Burollet, 1989; see previous paragraph) to a regressive sequence. This renders the proposed Cenomanian age for the base of the Nalut Fm highly improbable. In agreement with Busson (1967), we thus propose a strict Early Turonian age for this formation in Libya.

\subsection{Depositional environments}

The sedimentary facies identified from the Boulouha, Douiret and Kabaw Fms suggest deposition in a large shallow embayment, subject to salinity variations and tidal influence. Overall, the Kabaw Fm and the Boulouha-Douiret Fms succession record a second-order marine transgression, starting with fluvial sandstones at the base of the Kabaw Fm and the Boulouha Fm (Ouaja et al., 2002), and culminating with the deposition of the distal-marine green marls in the upper Douiret Fm, where marine ostracods, hybodont sharks and marine ray have been found (Bouaziz et al., 1989; Cuny et al., 2004; see also Anderson et al., 2007).

The Kiklah-Aïn el Guettar Fms were deposited in a similar type of shallow-marine embayment environment, subject to salinity variations and tidal influence. The facies are however more sanddominated. The two fining-upward cycles that characterize these formations record deepening upward cycles, and a vertical transition from fluvial to tidal and to more open-marine environment can be observed. The presence of neoselachian shark remains in the Chenini Mb (Cuny et al., 2004; see also Anderson et al., 2007) and marine bioturbation in the Oum ed Diab Mb supports the marine interpretation.

The Rhadouane and Kerker Mbs, and the Sidi as sid Fm, were deposited in an environment that was analogous to the presentday Shark Bay in Australia (Logan and Cebulski, 1970), i.e. a carbonate-dominated shallow-marine embayment, with development of widespread microbial mats, where hyper-salinity events lead to the deposition of evaporites. In proximal settings, accumulation of bivalves and gastropods result in the formation of thick bioclasticrich beds. 


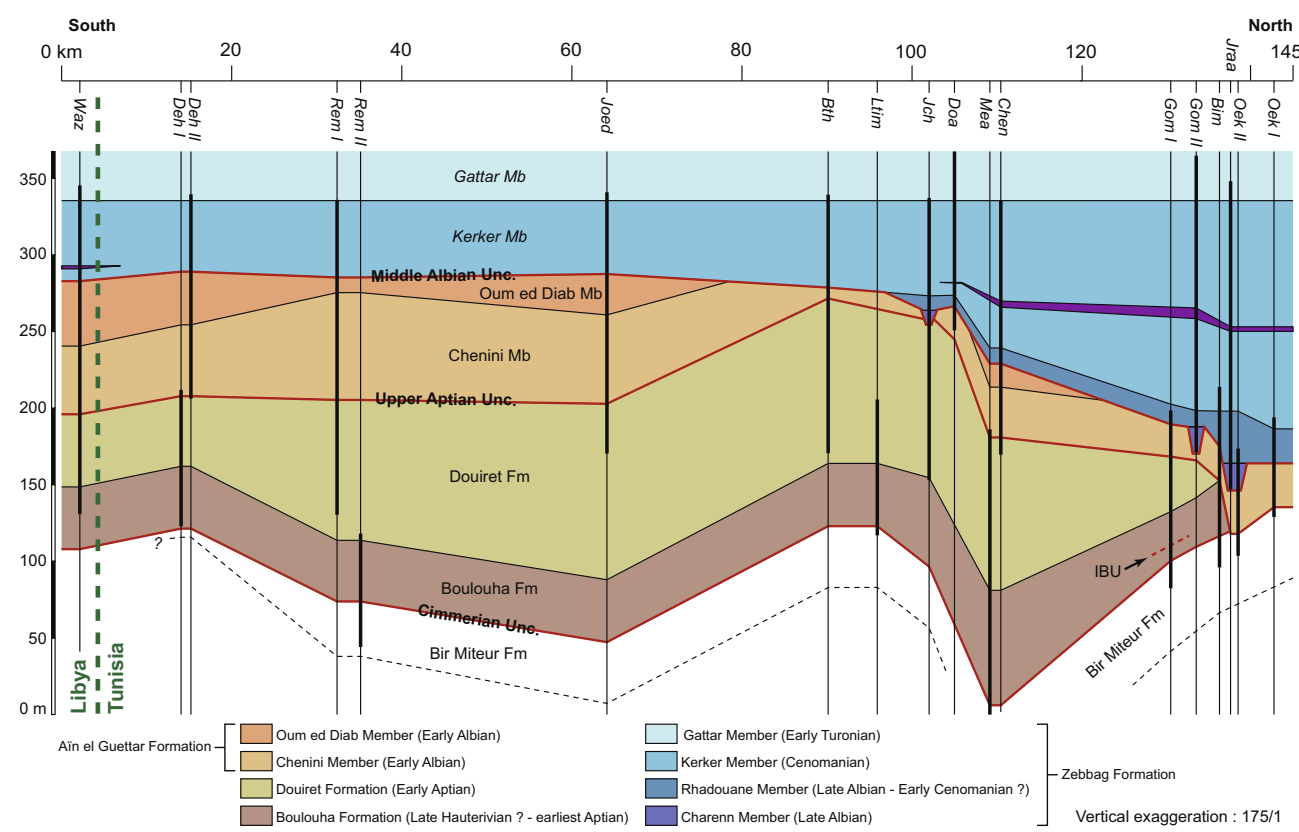

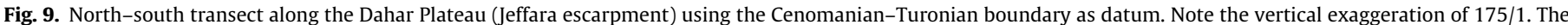

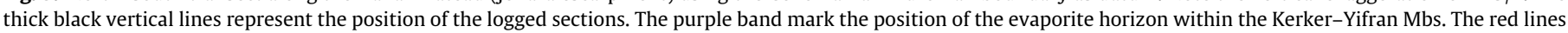

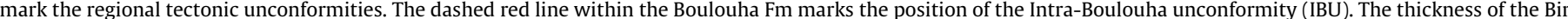

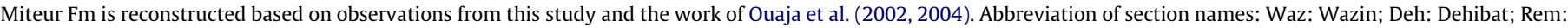

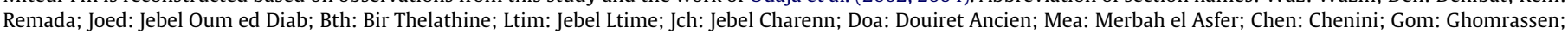
Bim: Bir Miteur; Jraa: Ksar Jraa; Oek: Oued el Khil.

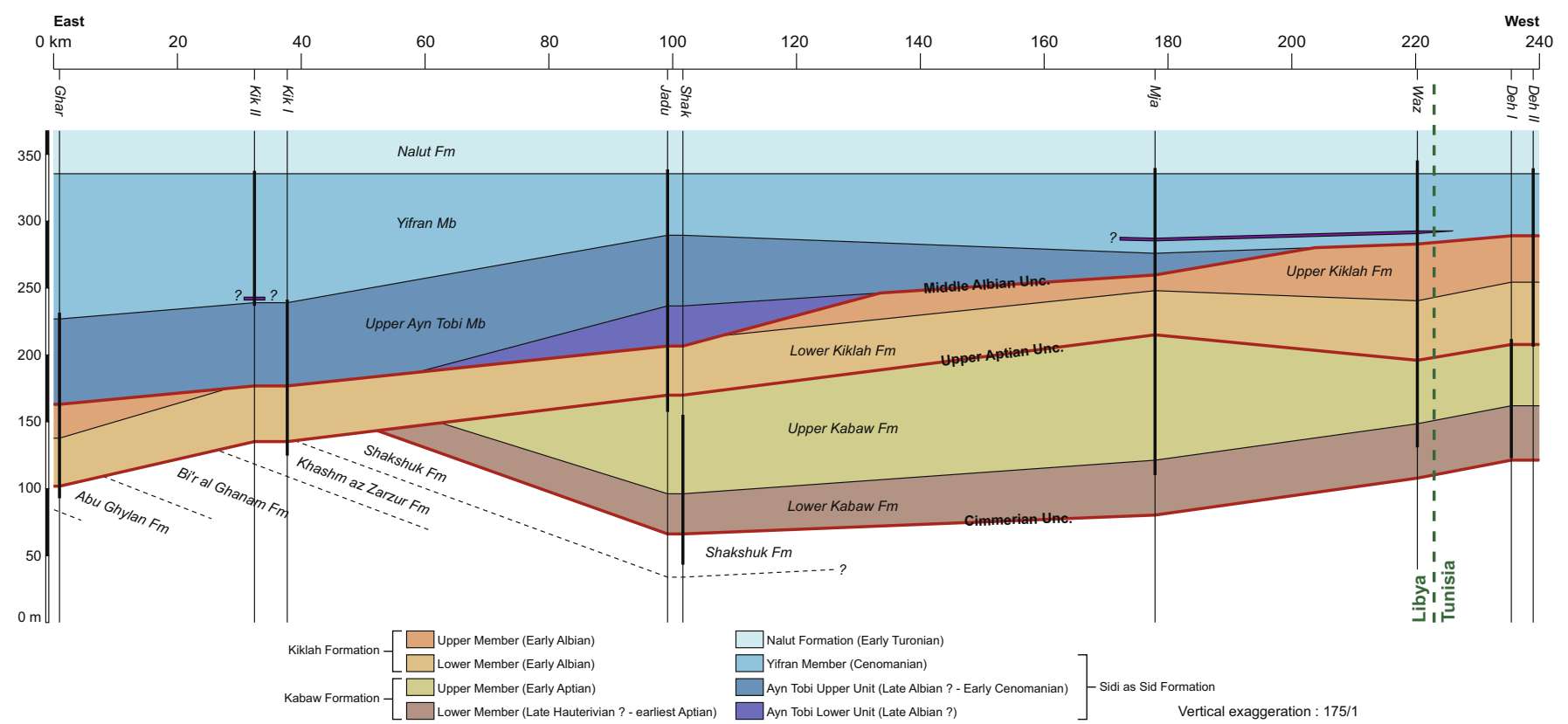

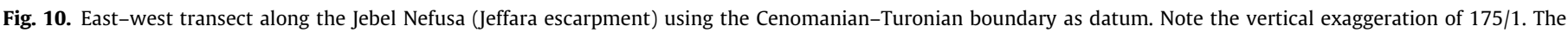

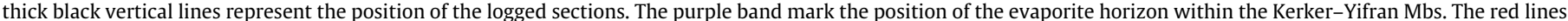
mark the regional tectonic unconformities. Abbreviation of section names: Ghar: Gharyan; Kik: Kiklah; Shak: Shakshuk; Mja: El Mjabrah; Waz: Wazin; Deh: Dehibat.

The Gattar Mb - Nalut Fm display facies that are typical of a carbonate platform. The presence of reef-like structures, rudist buildups, as well as a typical micro-fauna (Megerisi and Mamgain, 1980), would suggest that the Gattar Mb was deposited in a shallow marine, neritic environment, with connection to the open sea.

Apart for the Gattar-Nalut lithostratigraphic unit, which does not display any noticeable facies change throughout the studied area, an overall proximal-to-distal trend can be observed for Early to Mid-Cretaceous sedimentary units along the Jeffara escarpment from south to north. This trend is recorded by a progressive reduction in grain size to the north and enrichment of the sedimentary sequence in clay and marls. This pattern is consistent with models for the palaeogeography of North Africa at the time (Fig. 3 ) and the dominant palaeocurrent directions measured in sandstone packages, indicating a mean direction of transport toward the north (see also Ouaja et al., 2002). Lateral facies changes can also be observed, such as seen in the Kabaw Fm, which is dominated by siliciclastic sediments in the Shakshuk-Nalut area to the south in Libya, 
which contrasts with the more mud-dominated lithology elsewhere toward the north in Tunisia. A number of authors have suggested that this area was situated close to the palaeoriver mouth that was feeding this large shallow embayment with siliciclastic materials (e.g. Palaeo-Oued Tassili-Hamada in Lefranc and Guiraud (1990)).

\section{North Africa geodynamic implications}

\subsection{Timing of tectonic unconformities}

In Figs. 9 and 10, two geological transects across the Jeffara escarpment are displayed, using the Cenomanian-Turonian boundary as datum. They highlight the regional architecture of the Early to Mid-Cretaceous deposits along the Jeffara escarpment.

Stratigraphically, the Late Jurassic Bir Miteur-Shakshuk Fms are separated from the Early Cretaceous Boulouha-Kabaw Fms by a hiatus spanning the latest Kimmeridgian to the latest Hauterivian interval (Fig. 8). Ouaja et al. (2002, 2004) have moreover observed in Tunisia that this hiatus is associated with an angular unconformity in the southern part of the Dahar Plateau (see also Fig. 9), leading to the disappearance of the "Kimmeridgian bar" south of Remada. Poor outcrop conditions have prevented the tracking of the Shakshuk Fm (equivalent of the Bir Miteur Fm) in the western part of Jebel Nefusa. It is however present in the Shakshuk-Jadu area, ca. $100 \mathrm{~km}$ eastward of the border. As pointed out by Guiraud et al. (2005), tectonic deformations are recorded along most of North and Central African basins during the Jurassic-Cretaceous transition. This event is referred to as the Cimmerian unconformity and may reflect distant effects of tectonic activity in southeastern Europe.

Within the lower part of the Boulouha Fm, Ouaja et al. (2002) were the first to report the presence of a tectonic unconformity in the Tataouine area (Figs. 9 and 11a). This unconformity is only recognizable in this local region and is not expressed anywhere else along the Jeffara escarpment.

Along the north-south transect, two regional angular tectonic unconformities can be observed within Early to Mid-Cretaceous deposits. They bound the Aïn el Guettar Fm in Tunisia and are as such dated as Late Aptian and Middle Albian, respectively. Along the east-west transect, these two unconformities are also recognized and form the lower and upper boundaries of the Kiklah Fm in Libya (Fig. 10). This further strengthens the correlation between the Aïn el Guettar and Kiklah Fms. The Late Aptian unconformity is marked by the progressive truncation of pre-Middle Cretaceous sequences toward the north and the east. In Libya, this unconformity is well known and called the "Austrian tectonic unconformity" (e.g. Boote et al., 1998) and associated with the folding and regional tilting of Triassic and Jurassic sequence to the SSW (Magnier, 1963; Anketell and Ghellali, 1991). The Middle Albian unconformity is more difficult to observe at a regional scale in northwestern Libya but was already noticed by previous researchers working in the eastern part of Jebel Nefusa (Fig. 11b; Fatmi and Sbeta, 1991). The division of the Kiklah Fm into two members allows this unconformity to be better observed over the entire length of the Jebel Nefusa (Fig. 10).

The Middle Albian unconformity is best observed along the north-south transect in Tunisia, where it is marked by the folding and truncation of pre-Late Albian sequences. Further north of the studied area (Jebel Tebaga de Medenine), this unconformity is well expressed by the successive truncation of pre-Middle Cretaceous to Triassic sediment and the final superposition of the Rhadouane Mb over Late Permian marine sediments tilted toward the south (Fig. 11c; e.g. Bouaziz et al., 2002). In the Tataouine area, the presence of an anticlinal structure between the Merbah el Asfer and Je- bel Oum ed Diab region has already been documented by previous workers (Busson, 1967; Bouaziz et al., 1989) and was called the "Môle de Touil el Hira" (Touil el Hira High) by Bouaziz et al. (1989). In Libya, the Middle Albian unconformity is documented by an angular unconformity in the central Jebel Nefusa (Fig. 11b). It can also be recognized to the east of the studied area. Thus, along the eastern Jebel Nefusa, the Sidi as Sid Fm truncates the Kiklah Fm and can rest directly on the Late Triassic - earliest Jurassic Abu Shaybah Fm (Fatmi and Sbeta, 1991; see also Fig. 4.7 in Hallett (2002)). In the Sirt Basin, Ambrose (2000) observes an equivalent major unconformity at the top of the Albian Upper Sarir Fm, sealed by Cenomanian sediments, indicating that this is a regional and not just local feature.

\subsection{Discussion on the unconformities spatio-temporal exent}

In North Africa, a Mid-Cretaceous tectonic phase is well established by numerous workers and associated with the Austrian tectonic phase in the European Alps (e.g. Canerot et al., 1986; Guiraud et al., 1987, 2005; Badalini et al., 2002; see also Bulot and Ferry, 2007). However, numerous discrepancies exist with regards to its timing, depending on the under- and overlying sediment, and their dating accuracy.

In Libya, in the Ghadames Basin, the Austrian tectonic unconformity is associated with the unconformity at the base of Kiklah Fm (e.g. Dardour et al., 2004; Echikh, 1998). The Middle Albian unconformity is considered by previous worker to be a minor event compared to the Late Aptian one (e.g. Hallett, 2002). In the Hameimat Trough of the eastern Sirt Basin, Ambrose (2000) identified a major angular unconformity at the top of the Sarir Fm, near the Albian-Cenomanian boundary. A second less-well expressed unconformity is also present at the base of the Upper Sarir Sandstone (Rossi et al., 1991), dated as Late Aptian - Early Albian. Also, the presence of two Early Cretaceous tectonic unconformities has also been observed on recent 3D seismic lines offshore Libya ( $\mathrm{Al}$ Fraser, BP, pers. com.).

In Central Tunisia, Zouaghi et al. (2005) noted the presence of major unconformities interpreted from 2D seismic, dated as the Late Aptian - Early Albian and the Late Albian. Azaïez et al. (2007) attributed to the Austrian phase the Late Aptian tectonic unconformity that they observed in both field and seismic studies. Rigane et al. (2010) observed two tectonic unconformities in the tectonic evolution of the Jebel El Hamra tilted blocs, which they dated as Aptian-Albian in age. In the Chott area of Tunisia, a tectonic unconformity produces a sedimentary hiatus spanning the Late Aptian to Middle Albian (e.g. Ben Youssef and Peybernès, 1986; Lazzez et al., 2008). Bouaziz et al. (2002) noted the presence of transpressional events in Tunisia during the Late Aptian - Early Albian and the Middle (intra) Albian. Ben Slama et al. (2009) dated the extrusion of Triassic salt in Northern Tunisia from the Middle Albian. In their review of the Phanerozoic geological evolution of Northern and Central Africa, Guiraud et al. (2005) terminated their first Cretaceous rift phase during Early Aptian and associated it with the "Austrian" unconformity. Their second Cretaceous rift stage was terminated by the Late Albian regional unconformity. Pletsch et al. (2001) highlighted the presence of a Middle to Late Albian transition regional unconformity along the western African margin.

Following the result of our work and the comprehensive literature review, it is evident that the Aptian-Albian of North and Central Africa is characterized by the occurrence of two regional tectonic unconformities, dated as Late Aptian and Middle Albian, respectively (Fig. 12). Various authors apply the term "Austrian" unconformity only to the Late Aptian unconformity, whereas some authors apply this term to the Middle Albian unconformity as well. Care must therefore be taken in the future when referring to the 

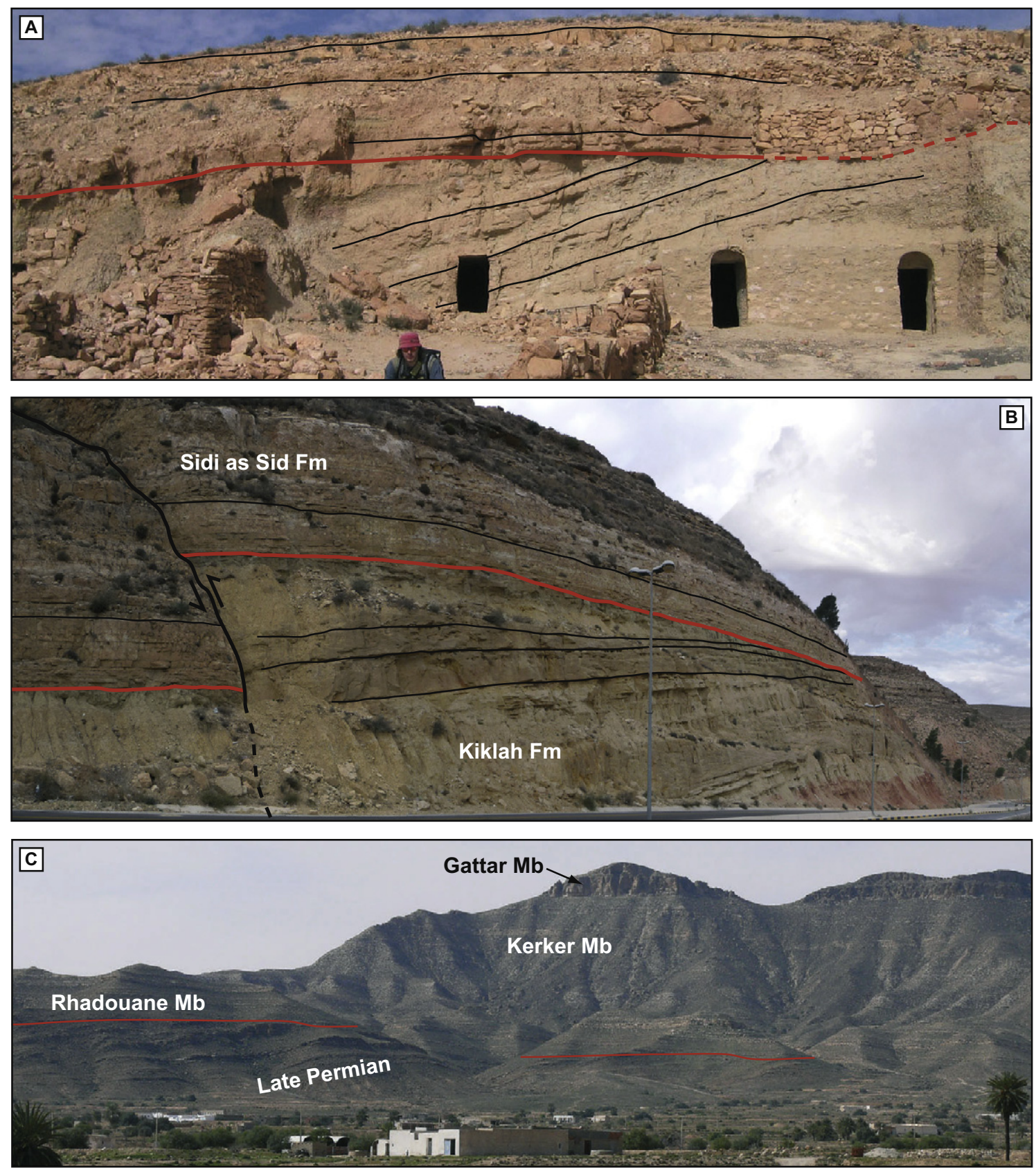

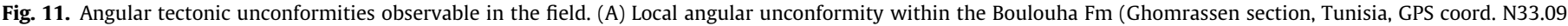

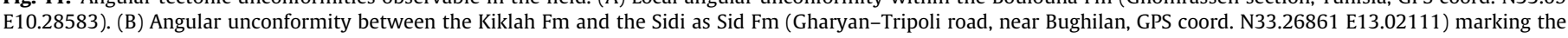

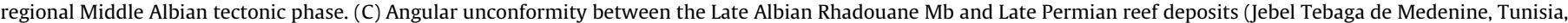
looking toward the West). The unconformity angle reaches $25^{\circ}$ (Bouaziz et al., 2002).

"Austrian" unconformity across North Africa. The term "Middle Cretaceous tectonic phase" should be preferentially used in order to avoid confusion when no precise dating can be achieved.

The local tectonic unconformity observed in the northern part of the Jeffara escarpment in Tunisia (Intra-Boulouha unconformity) is more difficult to relate to global geodynamics due to the absence of precise dating. Its position within the middle of the Boulouha Fm would point toward a Barremian age and would therefore correlate with the first Cretaceous syn-rift phase of Guiraud et al. (2005). In Fig. 12, we can observe that it is associated with a thickening of the Boulouha Fm and we can hypothesize that a local trough was created in this area at that time. However, in the absence of any other observation related to this unconformity, it is not possible to provide further precision.

\subsection{Link with the Atlantic Ocean opening}

Moulin et al. (2010) presented a new model for the timing of the opening of the Equatorial and South Atlantic Ocean. In this model, two critical stages occur during the Aptian-Albian transition and the Middle Albian: the opening of the Central South Atlantic and the Equatorial Atlantic Ocean, respectively. There is a striking correlation between this timing and the regional tectonic unconformities observed in Northern and Central Africa, which points toward a causal link (Fig. 12).

Anketell and Ghellali (1991) proposed that the unconformity at the base of the Kiklah Fm (i.e. the Late Aptian unconformity) was linked to the initiation of the Sabratah-Cyrenaica fault system in a compressional stress field resulting from sinistral shear on deep- 


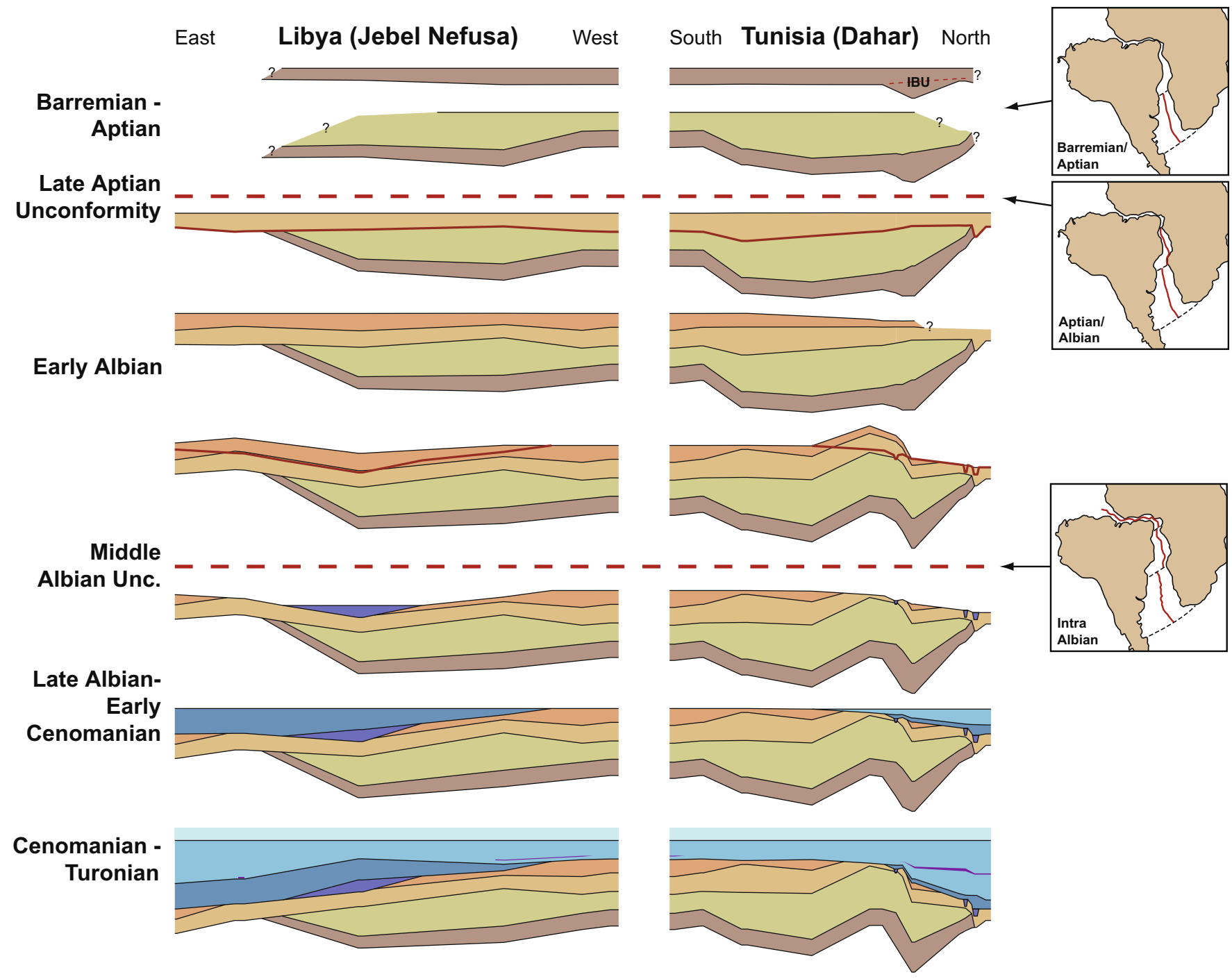

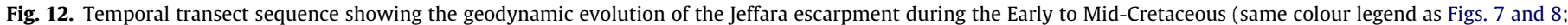
IBU: Intra-Boulouha unconformity) compared to the evolution of the Equatorial and South Atlantic Oceans (modified after Moulin et al. (2010)).

seated basement faults. The Aptian-Albian transition is also marked by the change from northwards to northeastwards movement of the Arabian-Nubian block relative to the West African block (Guiraud and Maurin, 1992). This time interval corresponds moreover to the change of the relative motion and the initiation of the convergence of Africa relative to Europe (Dewey et al., 1989; Rosenbaum et al., 2002). This support the interpretation that the Late Aptian unconformity is related to sinistral transpressive movement along the Sabratah-Cyrenaica fault system linked to the opening of the central segment of the South Atlantic Ocean and the northeastward movement of the Arabian-Nubian block.

The Middle Albian compressive event noted by previous authors in Tunisia (e.g. Bouaziz et al., 2002) has been explained by transpressive movement along the $10^{\circ} \mathrm{E}$ lineament. This tectonic phase is contemporaneous with the opening of the Equatorial Atlantic Ocean and the definitive separation of South America from Africa at about $105 \mathrm{Ma}$ (e.g. Fairhead and Binks, 1991; Moulin et al., 2010). The coeval timing of these two events suggests they are linked and that the Middle Albian unconformity represents intraplate deformation associated with changes in relative movement of the African blocks. Thus, it is proposed that the opening of the east-west orientated Equatorial segment may have induced a change in the stress regime of the West African block toward a north-south oriented compressional regime. A possible effect could be a northward movement of the West African block relative to the Arabian-Nubian block and the subsequent transpressional movement along the $10^{\circ} \mathrm{E}$ lineament.

\section{Conclusions}

Stratigraphic and sedimentological observations along the Jeffara escarpment in Tunisia and Libya allows us to confidently correlate the Libyan Kabaw Fm with the Tunisian Boulouha and Douiret Fms, the Kiklah Fm with the Aïn el Guettar Fm, the Sidi as Sid Fm with the Charenn, Rhadouane and Kerker Mbs, and the Nalut Fm with the Gattar Mb. A review of published paleontological data in these sediments on both sides of the border allows us to better constrain their dating. Thus, there is a major hiatus at the base of the Kabaw-Boulouha Fms, the latter being dated as latest Hauterivan-Barremian. Furthermore, the Libyan Kiklah Fm is dated as latest Aptian? - Early Albian.

A series of measured sections and detailed transects highlight four tectonic unconformities along the Jeffara escarpment. Above the basal Cimmerian unconformity, a local unconformity is recorded in Tunisia within the Boulouha Fm, in the northern part of the studied area. The two last tectonic unconformities are bounding the Kiklah - Aïn el Guettar Fms. These unconformities represent two regional tectonic events that can be recognized 
across Northern and Central Africa. They are dated as Late Aptian and Middle Albian, respectively. The Late Aptian unconformity is usually referred to as the Austrian unconformity. The Middle Albian unconformity correlates to the major tectonic unconformity also recognized at the top of the Sarir Fm (Nubian sandstone) throughout the Sirt Basin in Libya.

Placed into a plate tectonic context, there is a striking coeval timing between these unconformities and the evolution of the opening of the Equatorial and South Atlantic Ocean. Thus, the Late Aptian unconformity can be related to intra-plate deformation linked with the opening of the central segment of the South Atlantic and the accompanying sinistral movement of the Arabian-Nubian block during the Aptian-Albian transition. The Middle Albian unconformity relates to the opening of the Equatorial Atlantic and transpressive stress along the $10^{\circ} \mathrm{E}$ lineament, linked to north-south orientated movement of the West African block relative to the Arabian-Nubian block.

\section{Acknowledgments}

This study was funded by the North Africa Research Group (Manchester), sponsored by Maersk Oil, Hess, Anadarko, BG, Pluspetrol, Oxy, Wintershall, Repsol, RWE Dea, Petro-Canada, Woodside and ConocoPhilips. We thank Catherine Baudon (University of Manchester), Jamel Touir (University of Sfax), Faraj El-Khatri and Mohammed Rahoma (both of Libyan Petroleum Institute) for their help in the field. We are grateful to Pat Eriksson, Sebastian Lüning and an anonymous reviewer for their detailed comments which helped to improve this manuscript.

\section{References}

Abdallah, H., Meister, C., 1997. The Cenomanian-Turonian boundary in the GafsaChott area (southern part of central Tunisia): biostratigraphy, palaeoenvironments. Cretaceous Research 18, 197-236.

Abdallah, H., Memmi, L., 1994. Sur l'âge des “couches à Knemiceras” de Tunisie méridionale. Caractérisation de l'Albien supérieur (zone à Inflata et zone à Substuderi). Compte Rendus de l'Académie des Sciences 319, 337-340.

Abdelsalam, M.G., Liégeois, J.-P., Stern, R.J., 2002. The Saharan Metacraton. Journal of African Earth Sciences 34, 119-136.

Ambrose, G., 2000. The geology and hydrocarbon habitat of the Sarir sandstone, SE Sirt Basin, Libya. Journal of Petroleum Geology 23, 165-192.

Anderson, P.E., Benton, M.J., Trueman, C.N., Paterson, B.A., Cuny, G., 2007. Palaeoenvironments of vertebrates on the southern shore of Tethys: the nonmarine Early Cretaceous of Tunisia. Palaeogeography, Palaeoclimatology, Palaeoecology 243, 118-131.

Anketell, J.M., Ghellali, S.M., 1991. A palaeogeologic map of the pre-tertiary surface in the region of the Jifarah Plain and its implication to the structural history of Northern Libya. In: Salem, M.J., Sbeta, A.M., Bakbak, M.R. (Eds.), The Geology of Libya, vol. 6. Elsevier, Amsterdam, pp. 2381-2406.

Azaïez, H., Bédir, M., Tanfous, D., Soussi, M., 2007. Seismic sequence stratigraphy and platform to basin reservoir structuring of Lower Cretaceous deposits in the Sidi Aïch-Majoura region (Central Tunisia). Journal of African Earth Sciences 48, $1-18$.

Badalini, G., Redfern, J., Carr, I.D., 2002. A synthesis of current understanding of the structural evolution of North Africa. Journal of Petroleum Geology 25, 249-258.

Banerjee, S., 1980. Stratigraphic Lexicon of Libya, vol. 13. Department of Geological Research and Mining, Bulletin. $300 \mathrm{p}$.

Barale, G., Ouaja, M., 2002. La biodiversité végétale des gisements d'âge Jurassique supérieur-Crétacé inférieur de Merbah El Asfer (Sud-Tunisien). Cretaceous Research 23, 707-737.

Belhaj, F., 1996. Palaeozoic and Mesozoic stratigraphy of Eastern Ghadämis and Western Sirt Basins. In: Salem, M.J., Mouzughi, A.J., Hammuda, O.S. (Eds.), The Geology of Sirt Basin, vol. 1. Elsevier, Amsterdam, The Netherlands, pp. 5796.

Ben Ismaïl, M., Bouaziz, S., Almeras, Y., Clavel, B., Donze, P., Enay, R., Ghenmi, M. Tintant, H., 1989. Nouvelles données biostratigraphiques sur le Callovien et les facies “purbecko-wealdiens" (Oxfordien à Vraconien) dans la région de Tataouine (Sud Tunisien). Bulletin de la Société Géologique de France 5 (8), 353-360.

Ben Ismaïl, M.H., 1991. Les bassins mésozoïques (Trias à Aptien) du sud de la Tunisie: stratigraphie intégrée, caractéristiques géophysiques et évolution géodynamique. Université de Tunis II, $446 \mathrm{p}$.

Ben Slama, M.-M., Masrouhi, A., Ghanmi, M., Ben Youssef, M., Zargouni, F., 2009. Albian extrusion evidences of the Triassic salt and clues of the beginning of the Eocene atlasic phase from the example of the Chitana-Ed Djebs structure
(N.Tunisia): implication in the North African Tethyan margin recorded events, comparisons. Comptes Rendus Geoscience 341, 547-556.

Ben Youssef, M., 1999. Stratigraphie génétique du Crétacé de Tunisie. Micropaléontologie, stratigraphie séquentielle et géodynamique des bassins de la marge Sud et péri-téthysienne, $402 \mathrm{p}$.

Ben Youssef, M., Biely, A., Kamoun, Y., Zouari, H., 1985. L'Albien moyen-superieur à Knemiceras forme la base de la grande transgression crétacé au Tebaga de Medenine (Tunisie méridionale). Compte Rendus de l'Académie des Sciences 300, 965-968.

Ben Youssef, M., Peybernès, B., 1986. Données micropaléontologiques et biostratigraphiques nouvelles sur le Crétacé inférieur marin du Sud-Tunisien. Journal of African Earth Sciences 5, 217-231.

Benton, M.J., Bouaziz, S., Buffetaut, E., Martill, D., Ouaja, M., Soussi, M., Trueman, C.N., 2000. Dinosaurs and other fossil vertebrates from fluvial deposits in the Lower Cretaceous of southern Tunisia. Palaeogeography, Palaeoclimatology, Palaeoecology 157, 227-246.

Boote, D.R.D., Clark-Lowes, D.D., Traut, M.W., 1998. Palaeozoic petroleum systems of North Africa. In: MacGregor, D.S., Moody, R.T.J., Clark-Lowes, D.D. (Eds.), Petroleum Geology of North Africa, Geological Society of London, Special Publication. pp. 7-68.

Bouaziz, S., Barrier, E., Soussi, M., Turki, M.M., Zouari, H., 2002. Tectonic evolution of the northern African margin in Tunisia from paleostress data and sedimentary record. Tectonophysics 357, 227-253.

Bouaziz, S., Buffetaut, E., Ghanmi, M., Jaeger, J.-J., Martin, M., Mazin, J.-M., Tong, H., 1988. Nouvelles découvertes de vertébrés fossiles dans l'Albien du Sud Tunisien. Bulletin de la Société Géologique de France 4 (8), 335-339.

Bouaziz, S., Donze, P., Ghanmi, M., Zarbout, M., 1989. La série à dominate continentale (Oxfordien à Cénomanien) de la falaise du Dahar (Sud Tunisien); son évolution du Tebaga de Medenine à la frontière tripolitaine. Géologie Méditerranéenne 16, 67-76.

Buffetaut, E., Ouaja, M., 2002. A new specimen of Spinosaurus (Dinosauria, Theropoda) from the Lower Cretaceous of Tunisia, with remarks on the evolutionary history of the Spinosauridae. Bulletin de la Société Géologique de France 173, 415-421.

Bulot, L.G., Ferry, S., 2007. La discontinuité albienne à l'échelle globale et ses implications paléobiogéographiques et biostratigraphiques. Carnet de Géologie/ Notebooks on Geology CG2007_M02/11, pp. 56-59.

Burollet, P.F., 1989. Les évènements du Crétacé moyen au Sud de la Méditerranée. Géobios, Mémoire Spécial 11, 69-81.

Busson, G., 1967. Le Mésozoïque saharien. 1re partie: l'extrême-Sud tunisien, Centre de Recherches sur les zones arides, Série Géologie, No. 8, CNRS, 194 p.

Canerot, J., Cugny, P., Peybernès, B., Rahhali, I., Rey, J., Thieuloy, J.-P., 1986. Comparative study of the Lower and Mid-Cretaceous sequences on different Maghrebian shelves and basins - their place in the evolution of the North African Atlantic and Neotethysian margins. Palaeogeography, Palaeoclimatology, Palaeoecology 55, 213-232.

Chaabani, F., Manaai, M., Souissi, F., Souissi, R., Sassi, S., 2003. Dolomitization and calcitization stages in rocks of the Nalut Formation, Jabal Nafüsah, NW Libya. In: Salem, M.J., Oun Khaled, M., Seddiq Hussein, M. (Eds.), Geology of North West Libya. Second Symposium on the Sedimentary Basins of Libya, vol. I. Earth Science Society of Libya, Tripoli, Libya, pp. 171-182.

Christie, A.M., 1955. Geology of the Garian Area. United Nations Technical Assistance Program, New York, Report TAA/LIB/2 (Re-published in 1966 by the Geological Survey, Ministry of Industry, Kingdom of Libya, Geological Section Bulletin No. 6), p. 60.

Cuny, G., Ouaja, M., Srarfi, D., Schmitz, L., Buffetaut, E., Benton, M.J., 2004. Fossil sharks from the Early Cretaceous of Tunisia. Revue de Paléobiologie, Genève 9 , 127-142.

Dardour, A.M., Boote, D.R.D., Baird, A.W., 2004. Stratigraphic controls on palaeozoic petroleum systems, Ghadames Basin, Libya. Journal of Petroleum Geology 27, $141-162$.

Desio, A., Rossi Ronchetti, C., Pozzi, R., Clerici, F., Invernizzi, G., Pisoni, C., Vigano, P., 1963. Stratigraphic studies in the Tripolitanian Jebel (Libya). Rivista Italiana di Paleontologia y Stratigraphiae Memorie IX, 1-126.

Dewey, J.F., Helman, M.L., Turco, E., Hutton, D.W.H., Knott, S.D., 1989. Kinematics of the western Mediterannean. In: Coward, M.P., Dietrich, D., Park, R.G. (Eds.), Alpine Tectonics, Geological Society of America, Special Publication 45, pp. 265-283.

Echikh, K., 1998. Geology and hydrocarbon occurrences in the Ghadames Basin, Algeria, Tunisia, Libya. In: MacGregor, D.S., Moody, R.T.J., Clark-Lowes, D.D. (Eds.), Petroleum Geology of North Africa, Geological Society, London, Special Publication, pp. 109-129.

El Hinnawy, M., Cheshitev, G., 1975. Geological Map of Libya 1:250,000, Sheet Tarabulus, NI 33-13, Explanotary Booklet.

El-Bakai, M.T., 1997. Petrography and palaeoenvironment of the Sidi as Sid Formation in Northwest Libya. Petroleum Research Journal 9, 9-26.

El-Zouki, A.Y., 1980a. Depositional environments of the Chicla, Cabao and Chameau Mort formations as revealed by scanning electron microscopy. In: Salem, M.J., Busrewil, M.T. (Eds.), The Geology of Libya, vol. 2. Academic Press, London, pp. 419-426.

El-Zouki, A.Y., 1980b. Stratigraphy and lithofacies of the continental clastics (Upper Jurassic and Lower Cretaceous) of Jabal Nafüsah, NW Libya. In: Salem, M.J., Busrewil, M.T. (Eds.), The Geology of Libya, vol. 2. Academic Press, London, pp. 393-418.

Fairhead, J.D., Binks, R.M., 1991. Differential opening of the Central and South Atlantic Oceans and the opening of the West African rift system. Tectonophysics 187, 191-203. 
Fatmi, A.N., Sbeta, A.M., 1991. The significance of the occurrence of Abu Ghaylan and Kiklah Formations east of Wädi Ghän, Eastern Jabal Nefusah. In: Salem, M.J. Sbeta, A.M., Bakbak, M.R. (Eds.), The Geology of Libya, vol. 6. Elsevier, Amsterdam, pp. 2227-2233.

Galeazzi, S., Point, O., Haddadi, N., Mather, J., Druesne, D., 2010. Regional geology and petroleum systems of the Illizi-Berkine area of the Algerian Saharan platform: an overview. Marine and Petroleum Geology 27, 143-178.

Guiraud, R., Bellion, Y., Benkhelil, J., Moreau, C., 1987. Post-Hercynian tectonics in the Northern and Western Africa. Geological Journal 22, 433-466.

Guiraud, R., Bosworth, W., Thierry, J., Delplanque, A., 2005. Phanerozoic geological evolution of Northern and Central Africa: an overview. Journal of African Earth Sciences 43, 83-143.

Guiraud, R., Maurin, J.-C., 1992. Early Cretaceous rifts of Western and Central Africa: an overview. Tectonophysics $213,153-168$.

Hallett, D., 2002. Petroleum Geology of Libya. Elsevier, Amsterdam, The Netherlands. 503 p.

Hammuda, O.S., Sbeta, A.M., Worsley, D., 2000. Field guide to the Mesozoic succession of Jabal Nefusah, NW Libya. In: Sedimentary Basins of Libya - Second Symposium. Geology of Northwest Libya, p. 50.

Kamoun, F., Peybernes, B., Montacer, M., Ben Youssef, M., 2003. Sequence stratigraphy, micropalaeontology and palaeogeography of the Jurassic series of Southern Tunisia. In: Salem, M.J., Oun Khaled, M., Seddiq Hussein, M. (Eds.), Geology of North West Libya. Second Symposium on the Sedimentary Basins of Libya, vol. I. Tripoli, Libya, Earth Science Society of Libya, pp. 79-98.

Klitzsch, E., Squyres, C.H., 1990. Paleozoic and mesozoic geological history of northeastern Africa based upon new interpretation of Nubian strata. AAPG Bulletin 74, 1203-1211.

Lazzez, M., Zouaghi, T., Ben Youssef, M., 2008. Austrian phase on the northern African margin inferred from sequence stratigraphy and sedimentary records in southern Tunisia (Chotts and Djeffara areas). Comptes Rendus Geoscience 340, 543-552.

Lefranc, J.P., Guiraud, R., 1990. The continental intercalaire of northwestern Sahara and its equivalents in the neighbouring regions. Journal of African Earth Sciences 10, 27-77.

Liégeois, J.-P., Benhallou, A., Azzouni-Sekkal, A., Yahiaoui, R., Bonin, B., 2005. The Hoggar swell and volcanism: reactivation of the Precambrian Tuareg shield during Alpine convergence and West African Cenozoic volcanism. In: Foulger, G.R., Natland, J.H., Presnall, D.C., Anderson, D.L. (Eds.), Plates. Plumes and Paradigms, Geological Society of America Special Paper 388, pp. 379-400.

Logan, B.W., Cebulski, D.E., 1970. Sedimentary environments of Shark Bay, Western Australia. In: Logan, B.W., Davies, G.R., Read, J.F., Cebulski, D.E. (Eds.), Carbonate Sedimentation and Environments. AAPG Memoir, Shark Bay, Western Australia, pp. 1-37.

Lüning, S., Kolonic, S., Belhadj, E.M., Belhadj, Z., Cota, L., Baric, G., Wagner, T., 2004 Integrated depositional model for the Cenomanian-Turonian organic-rich strata in North Africa. Earth-Science Reviews 64, 51-117.

M'Rabet, A., Mejri, F., Burollet, P.F., Memmi, L., Chandoul, H., 1995. Catalog of type sections in Tunisia, Cretaceous, Entreprise Tunisienne d'Activités Pétrolières, Memoir n 8A, 123 p.

Magnier, P., 1963. Etude stratigraphique dans le Gebel Nefousa et le Gebel Garian (Tripolitaine, Libye). Bulletin de la Société Géologique de France (série 7) 5, 89-94.

Masse, J.P., Bellion, Y., Benkhelil, J., Ricou, L.E., Dercourt, J., Guiraud, R., 1993. Early Aptian (114 to $111 \mathrm{Ma}$ ). Atlas, Tethys, Palaeoenvironmental Maps. BEICIPFRANLAB, Rueil-Malmaison.
Megerisi, M.F., Mamgain, V.D., 1980. The Upper Cretaceous - Tertiary Formations of Northern Libya: A Synthesis. Industrial Research Centre, Tripoli, Department of Geological Researches and Mining, Bulletin, vol. 12, 86 p.

Moulin, M., Aslanian, D., Unternehr, P., 2010. A new starting point for the south and equatorial Atlantic Ocean. Earth-Science Reviews 98, 1-37.

Newell, N.D., Rigby, J.K., Driggs, A., Boyd, D.W., Stehli, F.G., 1976. Permian reef complex, Tunisia. Brigham Young University Geology Studies 23, 72-112.

Ouaja, M., Ferry, S., Barale, G., Srarfi, D., 2002. Faciès de dépôt du Jurassique et du Crétacé du Bassin de Tataouine (Sud de la Tunisie). Field Excursion Guidebook, Association des Sédimentologistes Français, 20-26 October 2002, 100 p.

Ouaja, M., Philippe, M., Barale, G., Ferry, S., Ben Youssef, M., 2004. Mise en évidence d'une flore oxfordienne dans le Sud-Est de la Tunisie: intérêts stratigraphique et paléoécologique. Geobios 37, 89-97.

Peybernès, B., Almeras, Y., Ben Youssef, M., Kamoun, F., Mello, J., Rey, J., Zargouni, F. 1985. Nouveaux éléments de datation dans le Jurassique du Sud-tunisien (plate-forme saharienne). Comptes Rendus de l'Academie des Sciences - Series IIA - Earth and Planetary Science 300, 113-118.

Peybernès, B., Vila, J.-M., Souquet, P., Charrière, A., Ben Youssef, M., Zarbout, M. 1996. Trois gisements de Brachiopodes dans le Crétacé inférieur tunisien. Batalleria (Barcelona) 6, 45-58

Pletsch, T., Erbacher, J., Holbourn, A.E.L., Kuhnt, W., Moullade, M., Oboh-Ikuenobede F.E., Söding, E., Wagner, T., 2001. Cretaceous separation of Africa and South America: the view from the West African margin (ODP Leg 159). Journal of South American Earth Sciences 14, 147-174.

Razgallah, S., Philip, J., Thomel, G., Zaghbib-Turki, D., Chaabani, F., Ben Haj Ali, N., M'Rabet, A., 1994. La limite Cénomanien-Turonien en Tunisie centrale et méridionale: biostratigraphie et paléoenvironnements. Cretaceous Research 15, 507-533.

Rigane, A., Feki, M., Gourmelen, C., Montacer, M., 2010. The "Aptian Crisis" of the South-Tethyan margin: new tectonic data in Tunisia. Journal of African Earth Sciences 57, 360-366

Rosenbaum, G., Lister, G.S., Duboz, C., 2002. Relative motions of Africa, Iberia and Europe during Alpine orogeny. Tectonophysics 359, 117-129.

Rossi, M.E., Tonna, M., Larbash, M., 1991. Latest Jurassic - Early Cretaceous deposits in the subsurface of the Eastern Sirt Basin (Libya): facies and relationships with tectonics and sea-level changes. In: Salem, M.J., Sbeta, A.M., Bakbak, M.R. (Eds.), The Geology of Libya, vol. 6. Elsevier, Amsterdam, pp. 2211-2225.

Soussi, M., 2003. New Jurassic lithostratigraphic chart for the Tunisian atlas. Geobios 36, 761-773.

Tawadros, E.E., 2001. Geology of Egypt and Libya: Rotterdam. A.A. Balkema Publishers, The Netherlands. $468 \mathrm{p}$.

Tekbali, A.O., 2000. Pollen \& Spores from Subsurface Albian of the Kiklah Formation NW Libya. International workshop on North African Micropalaeontonlogy for Petroleum Exploration, p. 70.

Underdown, R., Redfern, J., Lisker, F., 2007. Constraining the burial history of the Ghadames Basin, North Africa: an integrated analysis using sonic velocities vitrinite reflectance data and apatite fission track ages. Basin Research 19, 557578.

Ward, J.V., Tekbali, A.O., Doyle, J.A., 1987. Palynology of the Kiklah Formation (Cretaceous). In: 3rd Symposium of the Geology of Libya, Abstract volume. Tripoli, North Western Libya, p. 123.

Zouaghi, T., Bédir, M., Inoubli, M.H., 2005. 2D Seismic interpretation of strike-slip faulting, salt tectonics, and Cretaceous unconformities, Atlas Mountains, central Tunisia. Journal of African Earth Sciences 43, 464-486. 